\title{
Uma abordagem estrutural para deteç̧ão de objetos e localização em ambientes internos por dispositivos móveis
}

\author{
Henrique Morimitsu \\ DiSSERTAÇÃO APRESENTADA \\ $\mathrm{AO}$ \\ Instituto DE MATEMÁticA E EstatísticA \\ DA \\ Universidade DE SÃo Paulo \\ PARA \\ OBTENÇÃO DO TÍTULO \\ $\mathrm{DE}$ \\ Mestre em CiÊnCIAS \\ Programa: Ciência da Computação \\ Orientador: Prof. Dr. Roberto Marcondes Cesar Junior
}

Durante o desenvolvimento deste trabalho o autor recebeu auxílio financeiro da FAPESP, CNPq e FINEP

São Paulo, agosto de 2011 


\section{Uma abordagem estrutural para detecção de objetos e localização em ambientes internos por dispositivos móveis}

Esta versão definitiva da dissertação contém as correções e alterações sugeridas pela Comissão Julgadora durante a defesa realizada por Henrique Morimitsu em 29/08/2011.

Comissão Julgadora:

- Prof. Dr. Roberto Marcondes Cesar Junior (orientador) - IME-USP

- Prof. Dr. Roberto Hirata Junior - IME-USP

- Profa. Dra. Anna Helena Reali Costa - EP-USP 


\section{Agradecimentos}

Primeiramente, agradeço à minha família, por sempre ter me apoiado a seguir pelo caminho em que estou agora e sem os quais eu certamente não teria chegado até aqui. Devo muitos agradecimentos ao meu orientador, professor Roberto Cesar, que sempre me motivou muito e acreditou em mim para o desenvolvimento deste trabalho. Agradeço também a todos os colegas que conheci no grupo durante esta fase de minha vida e que contribuíram de muitas formas para tornar a minha permanência aqui muito mais agradável. Dentre os quais, tive especial contato com o professor Roberto Hirata, Charles Iury, Willian Honda, Marcelo Hashimoto, Andréa Mattos, Jesús MenaChalco, Rodrigo Pimentel e Alexandre Harano que me ajudaram e ensinaram muito tanto na vida acadêmica, quanto no cotidiano.

Nada disso teria sido possível também sem a presença dos professores Esteban Tuesta, Patrícia Oliveira e Marcone Pereira, que não só acreditaram em mim logo no início de minha carreira, como também foram fundamentais para que eu chegasse onde estou. Assim, agradeço profundamente à eles por todo o apoio.

Agradeço ao Instituto de Matemática e Estatística como um todo por me acolher. E também às instituições FAPESP, CNPq e FINEP pelo suporte financeiro, que viabilizou o desenvolvimento deste trabalho. 


\section{Resumo}

A detecção de objetos é uma área de extrema importância para sistemas de visão computacional. Em especial, dado o aumento constante da utilização de dispositivos móveis, torna-se cada vez mais importante o desenvolvimento de métodos e aplicações capazes de serem utilizadas em tais aparelhos. Neste sentido, neste trabalho propõe-se o estudo e implementação de um aplicativo para dispositivos móveis capaz de detectar, em tempo real, objetos existentes em ambientes internos com uma aplicação para auxiliar um usuário a se localizar dentro do local.

O aplicativo depende somente das capacidades do próprio aparelho e, portanto, procura ser mais flexível e sem restrições. A detecção de objetos é realizada por casamento de grafos-chave entre imagens de objetos pré-escolhidas e a imagem sendo capturada pela câmera do dispositivo. Os grafos-chave são uma generalização do método de deteç̧ão de pontos-chave tradicional e, por levarem em consideração um conjunto de pontos e suas propriedades estruturais, são capazes de descrever e detectar os objetos de forma robusta e eficiente.

Para realizar a localização, optou-se por detectar placas existentes no próprio local. Após cada deteç̧ão, aplica-se um simples, mas bastante eficaz, sistema de localização baseado na comparação da placa detectada com uma base de dados de imagens de todo o ambiente. A base foi construída utilizando diversas câmeras colocadas sobre uma estrutura móvel, capturando sistematicamente imagens do ambiente em intervalos regulares.

A implementação é descrita em detalhes e são apresentados resultados obtidos por testes reais no ambiente escolhido utilizando um celular Nokia N900. Tais resultados são avaliados em termos da precisão da deteç̧ão e da estimativa de localização, bem como do tempo decorrido para a realização de todo o processo.

Palavras-chave: Detecção de objetos, dispositivos móveis, grafos-chave, localização. 


\section{Abstract}

Object detection is an area of extreme importance for computer vision systems. Specially because of the increasing use of mobile devices, it becomes more and more important to develop methods and applications that can be used in such devices. In this sense, we propose the study and implementation of an application for mobile devices that is able to detect, in real time, existing indoor objects with an application to help a user in localization in the environment.

The application depends solely on the device capabilities and hence, it is flexible and unconstrained. Object detection is accomplished by keygraph matching between images of previously chosen signs and the image currently being captured by the camera device. Keygraphs are a generalization of the traditional keypoints method and, by taking into consideration a set of points and its structural properties, are capable of describing the objects robustly and efficiently.

In order to perform localization, we chose to detect signs existing in the environment. After each detection, we apply a simple, but very effective, localization method based on a comparison between the detected sign and a dataset of images of the whole environment. The dataset was built using several cameras atop a mobile structure, systematically capturing images of the environment at regular intervals.

The implementation is described in details and we show results obtained from real tests in the chosen environment using a Nokia N900 cell phone. Such results are evaluated in terms of detection and localization estimation precision, as well as the elapsed time to perform the whole process.

Keywords: Object detection, mobile devices, keygraphs, localization. 


\section{Sumário}

$\begin{array}{ll}\text { Lista de Abreviaturas } & \text { ix }\end{array}$

Lista de Figuras

Lista de Tabelas $\quad$ xiii

1 Introdução $\quad 1$

1.1 Motivação . . . . . . . . . . . . . . . . . . . . . . . . . . 1

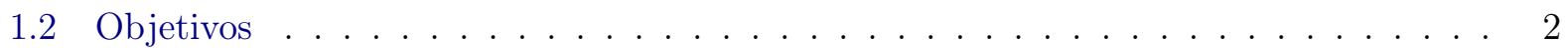

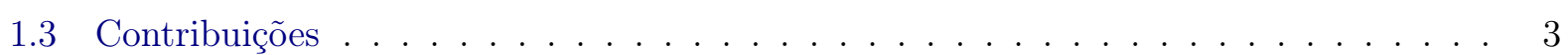

1.4 Organização do Trabalho . . . . . . . . . . . . . . . . . . . . . 3

2 Trabalhos relacionados $\quad 5$

2.1 Deteç̧ão de objetos em dispositivos móveis . . . . . . . . . . . . . . . 5

2.2 Métodos de localização . . . . . . . . . . . . . . . . . . . . . . 7

3 Grafos-chave $\quad 9$

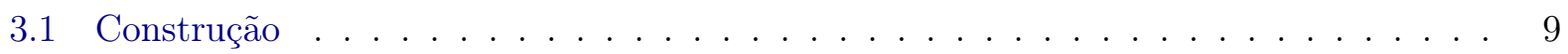

3.2 Fases de indexação e busca . . . . . . . . . . . . . . . . . . . . 10

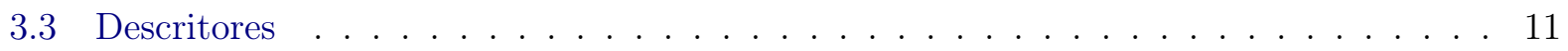

3.3 .1 Perfis de intensidade . . . . . . . . . . . . . . . . . . 11

3.3.2 Transformada de Fourier . . . . . . . . . . . . . . . . . . . . 12

3.4 Restrições . . . . . . . . . . . . . . . . . . . . . . . . . . 13

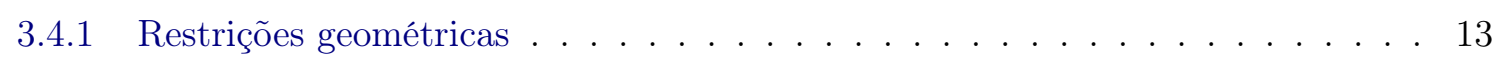

3.4 .2 Planaridade de grafos-chave . . . . . . . . . . . . . . . . . . . . . . 14

3.4 .3 Restrições adicionais para dispositivos móveis . . . . . . . . . . . . . . 15

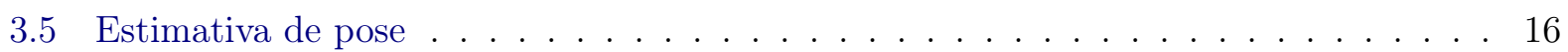

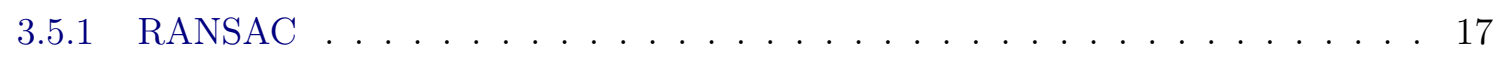

4 Sistema de detecção móvel $\quad 21$

4.1 Construção da base de dados de imagens . . . . . . . . . . . . . . . . . . . . . . . 22

4.2 Método de localização . . . . . . . . . . . . . . . . . . . . . . . 24

5 Resultados $\quad 27$

5.1 Deteç̧ão das placas . . . . . . . . . . . . . . . . . . . 27

$5.1 .1 \quad$ Precisão e robustez . . . . . . . . . . . . . . . . . . . . 28 
5.1 .2 Análise de tempo . . . . . . . . . . . . . . . . . . . . . . . . . 29

5.2 Estimativa de localização . . . . . . . . . . . . . . . . . . . . . 32

5.2 .1 Validação por morphing . . . . . . . . . . . . . . . . . . . . 32

6 Conclusões $\quad 37$

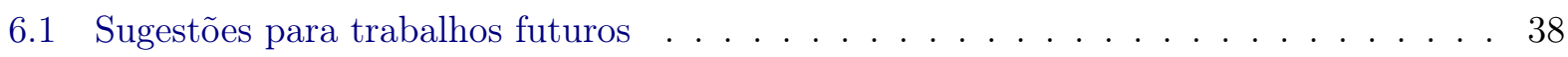

6.2 Trabalhos publicados . . . . . . . . . . . . . . . . . . . 39

Referências Bibliográficas $\quad 41$ 


\title{
Lista de Abreviaturas
}

\author{
GFTT Detector de pontos-chave Good Features to Track \\ MSER Detector de pontos-chave Maximally Stable Extremal Regions \\ RANSAC Algoritmo de ajuste Random Sample Consensus \\ SIFT Detector de pontos-chave Scale Invariant Feature Transform \\ SLAM Método de localização Simultaneous Localization and Mapping
}




\section{Lista de Figuras}

3.1 Exemplo de detecção por grafos-chaves. . . . . . . . . . . . . . . . . . . . . . 10

3.2 Perfil de intensidade de um arco . . . . . . . . . . . . . . . . . . . . . . 12

3.3 Formas de adição de arcos sobre 3 vértices dados. . . . . . . . . . . . . . . . . . . . . 14

3.4 Possíveis pontos (vértices) obtidos pela escolha de dois grafos-chave. . . . . . . . . 18

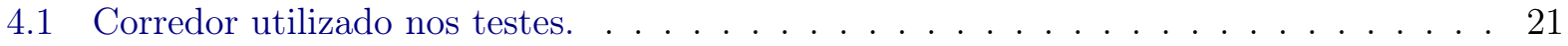

4.2 Placas a serem detectadas no corredor. . . . . . . . . . . . . . . . . . . . 22

4.3 Diagrama de funcionamento do aplicativo. . . . . . . . . . . . . . . . . . 22

4.4 Representação esquemática do processo de captura de imagens para formação da base de dados. . . . . . . . . . . . . . . . . . . . . . . . . . 23

4.5 Algumas imagens da base de dados. . . . . . . . . . . . . . . . . . . . . 24

4.6 Exemplos de imagens e a razão do tamanho da placa pelo tamanho total. . . . . . . . 25

4.7 Função distância obtida por meio da avaliação das imagens da base. . . . . . . . . . . 25

5.1 Interface gráfica do dispositivo. . . . . . . . . . . . . . . . . . . . . . 28

5.2 Detecção de placas pelo aplicativo. . . . . . . . . . . . . . . . . . . . . . . . . . 29

5.3 Comparação de tempo médio decorrido para cada passo da detecção usando 3 imagens modelo. . . . . . . . . . . . . . . . . . . . . . 30

5.4 Comparação de tempo médio decorrido para cada passo da detecção usando 500 imagens modelo. . . . . . . . . . . . . . . . . . . . . 31

5.5 Estimativa de localização. . . . . . . . . . . . . . . . . . . . . . . . . . . 32

5.6 Problema com o uso da base de imagens original. . . . . . . . . . . . . . . . 33

5.7 Novas imagens capturadas das placas e adicionadas à base de dados. . . . . . . . . . . 33

5.8 Marcações feitas sobre as imagens para o morphing. . . . . . . . . . . . . . . . . . 34

5.9 Imagens intermediárias obtidas por morphing. . . . . . . . . . . . . . . . . . 35

5.10 Comparativo da posição real com a posição estimada no corredor . . . . . . . . . . . 36

1 Histograma de referências bibliográficas . . . . . . . . . . . . . . . . . 44 


\section{Lista de Tabelas}

5.1 Comparação de taxa de detecções positivas de placas. . . . . . . . . . . . . . . . . . . 29

5.2 Desempenho do método de grafos-chaves de acordo com o número de modelos usados. 31

5.3 Testes de precisão da estimativa de localização. . . . . . . . . . . . . . . . . . . 35 


\section{Capítulo 1}

\section{Introdução}

\subsection{Motivação}

A detecção de objetos é uma importante área de pesquisa do campo de visão computacional. Apesar dos extensivos estudos já desenvolvidos, diversos problemas ainda se apresentam como um desafio até os dias de hoje. Em particular, dada a grande evolução dos dispositivos portáteis, há uma tendência cada vez maior de se desenvolver métodos que podem ser utilizados por tais dispositivos. Esses aparelhos, que atualmente oferecem a capacidade necessária para o tratamento de diversos problemas que antes só podiam ser tratados em grandes estações de trabalho, possibilitam o desenvolvimento de diversas novas tecnologias que até pouco tempo, eram totalmente inviáveis.

As aplicações para dispositivos móveis são diversas. Como será mais profundamente explorado no Capítulo 2, na área de deteç̧ão de objetos, pode-se citar, por exemplo, seu uso para extração de informações, localização, acessibilidade e realidade aumentada. Um exemplo particularmente interessante, que pode ser citado sobre este assunto, é a utilização de dispositivos móveis para deteç̧ão de objetos importantes num ambiente interno, como por exemplo, dentro de um edifício, para facilitar a localização e locomoção no local. De fato, este é um tópico cada vez mais estudado com aplicações nas áreas de tecnologias assistivas, facilitando o acesso a deficientes físicos, ou em robótica, para permitir que robôs naveguem automaticamente no ambiente, entre outras.

Porém, independentemente da aplicação específica, para que a deteç̧ão de objetos seja possível, é necessário que haja alguma forma de se descrever e comparar o objeto que se deseja encontrar. Neste sentido, uma técnica muito utilizada e que apresenta bons resultados é a detecção e casamento de pontos-chave. Diversos detectores de pontos-chave já foram propostos, tais como o detector de Shi e Tomasi (1994), SIFT (Lowe (2004)), SURF (Bay et al. (2008)), entre diversos outros. Cada detector tem suas particularidades, oferecendo maior robustez ao custo de sacrificar um pouco o desempenho, ou maior agilidade. Entretanto, os métodos de deteç̧ão baseados em pontos-chave sofrem do problema de tentar extrair muitas informações de pontos isolados da imagem (os pontoschave). De forma geral, cada ponto é tratado de forma individual, sem levar em consideração os demais pontos existentes e o seu relacionamento entre si. Para descrever uma imagem a partir de pontos-chaves, é comum se utilizar da informação obtida a partir da vizinhança de cada ponto-chave. Entretanto, essa abordagem apresenta algumas dificuldades como, por exemplo, a necessidade de se definir qual o tamanho ideal de vizinhança a ser considerado. Cada detector tem sua própria forma de lidar com este problema, atribuindo algum valor, ou região relativa ou absoluta ao redor de cada ponto para tratar da vizinhança, ou simplesmente atribuindo ao usuário a responsabilidade 
da escolha de um bom parâmetro para seu problema. Detectores mais robustos, como o SIFT, consideram também a orientação da vizinhança para descreverem a imagem. Assim, é necessário realizar um processamento adicional para se obter um vetor de orientação para cada ponto-chave da imagem.

Neste trabalho, é proposta a utilização de uma forma de deteç̧ão de objetos baseada na informação obtida de um conjunto de pontos simultaneamente. Tal método, chamado de detecção de grafos-chave (Hashimoto e Cesar-Jr. (2009)), consiste em descrever as imagens por grafos, ao invés de simples pontos, e detectar os objetos por meio da comparação dos grafos-chave de cada imagem. Os grafos-chave são interessantes pois, por considerar um conjunto de pontos e suas relações, oferecem informações estruturais das imagens que não estão disponíveis quando observa-se apenas pontos isolados. Como será mostrado no Capítulo 3, tal abordagem facilita a obtenção de descritores pequenos e robustos a diversas variações da imagem, bem como oferecem uma forma simples e direta de tratar alguns dos problemas apresentados que surgem com o uso de pontos-chave. Além disso, apesar de parecer que tal método pode aumentar a complexidade do problema, será mostrado também que, se bem utilizados, os grafos-chave podem, inclusive, melhorar o desempenho do processo de detecção, dada a simplicidade dos descritores obtidos e a sua consequente eficiência para comparação.

O foco deste trabalho será na utilização de dispositivos móveis para realizar a deteç̧ão de objetos existentes em ambientes internos, e mostrar que o método de detecção proposto é viável para ser implementado num dispositivo e executado em tempo real. Para demonstrar uma aplicação prática da deteç̧ão de objetos, optou-se por detectar placas existentes no local e utilizar a informação obtida para se estimar a localização do usuário no ambiente em que está inserido. A localização é realizada de forma bastante simples, baseando-se apenas na comparação entre as características da placa detectada com o conhecimento obtido a partir de um banco de dados com as informações de todo o ambiente em que se deseja navegar. Devido à sua simplicidade, o método de localização proposto apresenta algumas limitações. Por outro lado, sua implementação é muito eficiente e, para muitos casos, suas restrições podem ser razoáveis e suficientes para tratar o problema desejado.

Todo o processamento do aplicativo é realizado diretamente no aparelho, sem a necessidade de um servidor externo para auxiliar no processo. Além disso, o aplicativo depende apenas, tanto dos próprios componentes já existentes no aparelho, quanto de objetos do próprio ambiente. Isso permite que o aplicativo desenvolvido possa ser utilizado de forma muito mais livre, sem restrições adicionais.

\subsection{Objetivos}

O objetivo geral do mestrado é desenvolver e implementar métodos para dispositivos móveis que sejam capazes de detectar objetos em tempo real. Além disso, como uma aplicação especial, o aplicativo desenvolvido deve ser capaz de identificar a localização do usuário com base nas informações obtidas pela detecção. O método proposto é baseado na análise de informações estruturais dos objetos, que são obtidas através da construção de seus grafos-chave.

Os objetivos específicos do trabalho são os seguintes:

- Estudar e desenvolver métodos estruturais para detecção de objetos que possam ser implementados em dispositivos móveis; 
- Implementar um método capaz de identificar eficientemente a localização do usuário no ambiente comparando as informações obtidas pela fase de detecção com uma base de dados de imagens do ambiente utilizado;

- Desenvolver um aplicativo para dispositivos móveis que implemente os métodos estudados e que possa ser executado em tempo real.

\subsection{Contribuições}

Abaixo estão listadas as principais contribuições deste trabalho:

- Implementação de um método para detecção de placas e localização em ambientes internos com base em grafos-chave;

- Validação do método de casamento de grafos-chave como uma alternativa viável para implementação em dispositivos de capacidade reduzida;

- Validação do método de localização baseado em propriedades do objeto detectado como uma forma eficiente de implementação.

\subsection{Organização do Trabalho}

No Capítulo 2 são descritos os trabalhos de detecção de objetos e localização existentes. Os trabalhos foram divididos de acordo com a área específica a que pertencem. Outro aspecto importante, as considerações sobre o desempenho de cada um deles também são avaliadas.

No Capítulo 3 é apresentado o método de detecção de objetos por grafos-chave. Além dos conceitos básicos e considerações sobre suas vantagens e desvantagens, todos os elementos envolvidos no processo também são explicados, bem como algumas restrições particulares adotadas para dispositivos móveis.

No Capítulo 4 é explicada a metodologia utilizada para a implementação do aplicativo no dispositivo. Além disso é detalhada a forma de construção da base de dados de imagens do ambiente e sua aplicação na estimativa de localização.

No Capítulo 5 são mostrados os resultados obtidos pelo aplicativo desenvolvido. Os resultados são analisados levando em consideração: (i) a precisão e robustez na detecção e localização e (ii) o tempo médio necessário para o processamento de cada quadro de vídeo.

No Capítulo 6 são discutidas algumas conclusões obtidas neste trabalho. Também são apresentadas sugestões para pesquisas futuras. 


\section{Capítulo 2}

\section{Trabalhos relacionados}

\subsection{Detecção de objetos em dispositivos móveis}

O uso de aplicativos móveis para deteç̧ão de objetos é uma área bastante explorada atualmente e que conta com diversas abordagens para o tratamento dos problemas envolvidos. Um método bastante utilizado consiste em compensar a falta de processamento dos dispositivos com a utilização de um servidor remoto. Gammeter et al. (2010) realizam apenas processos mais simples de rastreamento diretamente no dispositivo móvel, e passam o processamento real de detecção para dois computadores externos conectados por uma rede sem fio. Esse método claramente oferece vantagens para o processamento de grandes volumes de dados, que podem ser inviáveis num dispositivo de capacidade reduzida. Entretanto, tal abordagem não é tão interessante para aplicações que dependem muito do servidor, pois frequentemente o tempo de transferência dos dados pela rede se torna o gargalo do sistema. Como pode ser observado no mesmo artigo, a latência verificada é da ordem de 2 segundos, que pode não ser aceitável para aplicações de execução em tempo real. Takacs et al. (2008) utilizam um celular para obter informações de objetos em ambientes externos com o uso de um celular. Apesar de usarem um modelo cliente-servidor, grande parte do processamento é realizado no próprio aparelho, tal como o próprio casamento de pontos-chave. Mesmo assim, porém, são obtidos resultados de cerca de 2,5 segundos por quadro, novamente com grande parte do tempo sendo despendido na troca de dados com o servidor.

Neste sentido, a fim de evitar o uso de componentes externos e suas dificuldades, mas tentando facilitar o processo de detecção por um aparelho móvel, outros autores propõem a inserção de marcadores artificiais no ambiente. Os marcadores são projetados de forma que sejam fáceis de reconhecer e, portanto, os resultados obtidos em geral são mais rápidos e precisos. Bagherinia e Manduchi (2011) obtêm taxas de até 5 quadros por segundo para a detecção do marcador, enquanto Mulloni et al. (2009) conseguem alcançar a marca de 15 quadros por segundo com marcadores detectados a até 4,5 metros de distância com uma taxa de acerto de $98 \%$. Porém, apesar de bastante promissora, essa abordagem depende muito da possibilidade da inserção de tais marcadores em todos os ambientes em que se deseja explorar. Isso não só pode trazer um grande custo adicional, como também faz-se necessário um estudo prévio sobre os locais que devem de fato receber cada marcador.

Uma alternativa para esse problema é realizar a deteç̧ão de objetos que fazem parte do próprio ambiente em que se deseja trabalhar. Apesar de objetos naturais serem em geral mais difíceis de se detectar, trabalhos anteriores demonstram que os dispositivos atuais já são capazes de realizar essa tarefa. Paucher e Turk (2010), em seu trabalho, demonstram uma aplicação do uso do detector 
SURF (Bay et al. (2008)) combinado com informações dos sensores do celular para se estimar a posição do usuário no ambiente. Para tanto, previamente constrói-se uma base de dados com informação dos pontos-chave e localização em 3D de alguns objetos particulares do ambiente que se deseja utilizar. Durante a detecção em tempo real, dados obtidos dos sensores acelerômetro, magnetômetro e GPS (se disponível) do celular são utilizados para se estimar a posição e pose mais provável do usuário e, com isso, limitar a busca na base de dados apenas aos objetos que podem ser vistos daquele local. Todo o processamento é realizado diretamente no próprio aparelho, mas devido ao uso de um dispositivo sem suporte nativo ao cálculo de número de ponto flutuante, todo o processo leva em torno de 10 segundos a cada quadro. Os autores também apresentam os resultados obtidos com o uso de um laptop, obtendo resultados muito mais razoáveis. Arth et al. (2009) também realizam no próprio celular o trabalho de deteç̧ão de localização e pose em ambientes internos. Para tanto, são utilizados um detector de pontos-chave proprietário, baseado no SURF e reconstrução 3D do ambiente. Assim como no trabalho anterior, os dados sobre todo o ambiente são coletados previamente e armazenados para posterior consulta. A partir de testes realizados utilizando dois celulares de capacidade relativamente elevada e para imagens de 640x480, os autores apresentam tempos de $350 \mathrm{~ms}$ e $615 \mathrm{~ms}$ em cada um dos aparelhos, valores aceitáveis para a necessidade de tempo real.

Uma área de aplicação particularmente importante e que está sendo bastante beneficiada pelos avanços na pesquisa de visão computacional móvel é o de desenvolvimento de tecnologias assistivas para deficientes visuais. Muitos dos trabalhos na área se concentram no auxílio a locomoção, permitindo não só que o deficiente seja capaz de chegar ao local que deseja de forma autônoma (Bagherinia e Manduchi (2011), Tian et al. (2010)), mas também que o faça de forma segura (Ivanchenko et al. (2010)). Outra área, não menos importante, trabalha no acesso à informação (Bigham et al. (2010), Bothe e Al-Hamdani (2010), Winlock et al. (2010)), dando ao deficiente a oportunidade de identificar informações sobre objetos de interesse de forma autônoma. Apesar de ainda haver muito a se fazer, os resultados têm se mostrado promissores, trazendo alguns benefícios reais com o uso da tecnologia para assistência desses usuários.

Pode-se verificar que, apesar de aplicações bastante variadas, muitos dos trabalhos se utilizam do método de detecção de pontos-chave para identificar o objeto procurado. Tal método é capaz de detectar consistentemente o objeto mesmo em condições mais adversas, tais como em mudanças de perspectiva, luz, entre outras. Entretanto, detectores robustos como o SIFT (Lowe (2004)), ainda são computacionalmente muito complexos para serem executados em dispositivos móveis. Mesmo detectores mais eficientes, como o SURF (Bay et al. (2008)), ainda assim não apresentam o tempo de resposta desejado. Trabalhos mais recentes como o de Leutenegger et al. (2011) ou o de Ambai e Yoshida (2011) mostram que o desenvolvimento de detectores mais eficientes continua sendo uma linha importante de pesquisa na atualidade. Neste sentido, a fim de se aproveitar do grande poder discriminativo obtido pelo uso de pontos-chave, mas também tentando obter um ganho de desempenho durante o processo, neste trabalho optou-se por utilizar o método de deteç̧ão de grafos-chave. Tal método, como será detalhado no capítulo seguinte, se utiliza do resultado obtido a partir de uma deteç̧ão de pontos-chave para construir grafos-chave, cujos descritores podem ser extraídos de forma bastante eficiente. Grafos-chave também apresentam algumas outras vantagens, como a consideração de informações estruturais dos objetos, capturadas pela estrutura dos grafos, que oferecem uma informação adicional para melhorar o processo de detecção. 


\subsection{Métodos de localização}

O problema de localização é bastante estudado principalmente na área de robótica, mas que também apresenta contribuições importantes no desenvolvimento de tecnologias assistivas para navegação em ambientes desconhecidos. Existem inúmeras abordagens para lidar com este problema. Em ambientes externos, é comum o uso de sinais de GPS, seja como método principal (Kahäri e Murphy (2006)), ou auxiliar (Kumar et al. (2008)) para se localizar. Entretanto, devido à sua imprecisão e à baixa intensidade de sinal, esta abordagem não é adequada para o uso em ambientes internos.

Um método de certa forma relacionado, mas mais adequado ao uso interno, é o do uso de sinais de redes sem fio para localização. Dada a realidade atual, em que redes sem fio podem ser encontradas em praticamente qualquer ambiente, a localização por sinais de rede certamente se mostra como uma alternativa interessante. Mesmo assim, ainda existem diversas dificuldades que podem dificultar sua aplicação. Primeiramente, é muito difícil de se calcular a atenuação real do sinal wi-fi dentro de um ambiente mais complexo com a presença de diversos objetos e constante movimentação. Além disso, devido à variação natural do sinal emitido por cada aparelho, a precisão da localização frequentemente é bastante comprometida. Como por ser visto no trabalho de Liu et al. (2007), a maioria dos métodos implementados apresentam erros da ordem de alguns metros, o que pode muitas vezes não ser suficiente para se tratar o problema de forma adequada. Além disso, a percepção do sinal das redes é altamente dependente dos componentes físicos utilizados tanto no emissor, quanto no receptor, o que inviabiliza o desenvolvimento de uma solução capaz de funcionar em qualquer ambiente. Diversas pesquisas, como a de Tsui et al. (2009), estão sendo desenvolvidas para contornar esta dificuldade, mas os resultados obtidos ainda não são ideais.

Outra área de estudos de localização é a baseada na comparação de imagens, que consiste em encontrar a imagem mais similar dentro de um banco de dados e, com isso, obter informações sobre o local. Esta abordagem é bastante usada para identificação de ambientes urbanos, onde o usuário captura uma imagem de algo que deseja reconhecer, ou obter mais informações e envia para um servidor que responde a sua requisição (Chen et al. (2011), Baatz et al. (2010), Gammeter et al. (2010)). Entretanto, ela também pode ser adequada para o uso em ambientes internos, como mostrado por Ravi et al. (2006). Neste trabalho, os autores criam uma base de dados de 300 cantos de salas descritos usando uma combinação de 3 métodos: histograma de cores, wavelets e casamento de formas. A localização consiste em determinar em qual sala o usuário está e para qual dos quatro cantos ele está direcionado. Com esta abordagem, os autores obtém taxas de acerto entre $80 \%$ a 90\%, mostrando a viabilidade do método para localização. No já citado trabalho de Paucher e Turk (2010), o uso de deteç̧ão de objetos permite que a localização seja estimada com apenas 10 a $15 \mathrm{~cm}$ de erro de precisão, o que demonstra a grande precisão que pode ser obtidas por meio de métodos baseados em visão computacional.

Em outro trabalho da área, ao invés de tentar procurar por um casamento de uma imagem específica, Yang e Tian (2010) propõem a deteç̧ão de um objeto mais geral, a saber, as portas do ambiente. Os autores se baseiam nas propriedades de portas em geral para detectá-las e propõem o seu uso como marcadores, ou para extrair informações sobre elas que permitam determinar a localização. Para a identificação de uma porta, os autores aplicam um detector de cantos e bordas na imagem, e consideram que uma porta é encontrada se forem detectados 4 cantos ligados por 4 bordas e que sigam algumas restrições geométricas. Os resultados mostram bastante robustez com 
precisão de cerca de $90 \%$ na detecção. 


\section{Capítulo 3}

\section{Grafos-chave}

Os grafos-chave são uma generalização dos pontos-chave para a detecção de objetos. Assim como para os pontos-chave, este método realiza a detecção com base em dois tipos de imagens: uma delas contendo somente o objeto que se deseja detectar (a imagem modelo) e a outra contendo o objeto do modelo, mas inserido em um ambiente qualquer (a imagem cena). No caso da cena, é comum que o ambiente em volta do objeto procurado seja complexo, contendo diversos outros objetos, mas que não são de interesse do detector. Além disso é possível que o próprio objeto buscado esteja sofrendo alguma variação, como por exemplo, estar sendo observado sob um ponto de vista diferente, causando alterações no seu tamanho ou distorções de perspectiva e luminosidade ou até mesmo oclusão. Isso acaba por dificultar o processo de deteç̧ão.

Para manter a boa precisão e robustez, muitos detectores de pontos-chave tradicionais utilizam vetores de muitas dimensões para descreverem cada um de seus pontos (128 dimensões para o SIFT e 64 para o SURF, por exemplo). Realizar o casamento de diversos desses vetores em tempo real pode se tornar inviável num dispositivo de baixa capacidade. Neste sentido, o uso de grafoschave pode ser uma alternativa interessante para contornar este problema e acelerar o processo de casamento. Como será visto adiante neste capítulo, os grafos-chave permitem que imagens sejam descritas utilizando vetores de dimensão muito menor e ainda assim oferecem grande robustez. A Figura 3.1 mostra um exemplo de deteç̧ão de objetos por meio de grafos-chave. Nas seções a seguir são apresentados mais detalhes sobre este método.

\subsection{Construção}

Os grafos-chave são digrafos construídos tomando um conjunto de pontos-chave como vértices e adicionando arcos dirigidos entre eles. Mais formalmente, pode-se definir um grafo-chave $G$ como um par $(V, E)$, sendo $V$ um subconjunto de um conjunto de pontos-chave $K$ e $E$ um subconjunto de $V^{2}$. O conjunto $K$ pode ser obtido por qualquer detector de pontos-chave conhecido, tais como MSER (Matas et al. (2002)), Good Features to Track (Shi e Tomasi (1994)), entre outros. Neste trabalho optou-se por utilizar o detector MSER. Esta escolha se deu devido à robustez oferecida por este detector, bem como sua grande eficiência para identificação dos pontos-chave. Além disso, como apontado por Tuytelaars e Mikolajczyk (2008), este detector é ideal para ser utilizado em objetos bem estruturados, tais como as placas usadas neste trabalho.

A fim de manter os grafos-chave comparáveis, todos eles são construídos seguindo as mesmas restrições e conjunto de regras de construção. Nesse sentido, uma propriedade importante que deve 


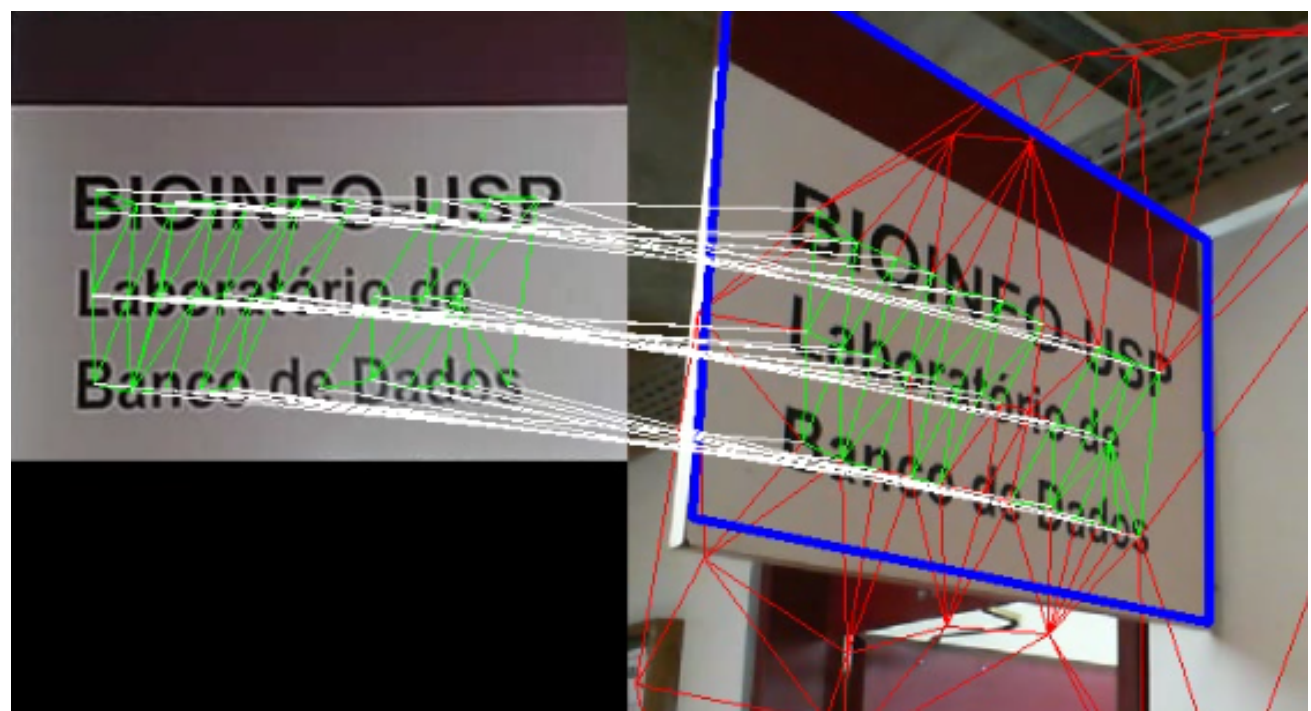

Figura 3.1: Exemplo de detecção por meio de grafos-chave. As linhas brancas entre as duas imagens indicam as correspondências obtidas. Os triângulos verdes nas duas imagens indicam os grafos-chave correspondidos. Os triângulos vermelhos na imagem direita mostram os grafos-chave não correspondidos.

ser mantida é que todos os grafos-chave devem possuir o mesmo número de vértices e arcos. $\mathrm{Na}$ realidade, a restrição imposta sobre todos os grafos-chave é um pouco mais forte. A fim de se estabelecer uma forma eficaz de comparação, define-se que a construção dos grafos-chave seja feita de forma que todos os sejam isomorfos entre si. Um isomorfismo entre dois grafos-chave $G$ e $H$ segue o mesmo conceito de isomorfismo entre digrafos tradicionais, i.e., trata-se de uma bijeção $f$ entre os conjuntos de vértices $V(G)$ e $V(H)$ :

$$
f: V(G) \rightarrow V(H)
$$

tal que um arco de $u$ incide em $v$ em $G$ se, e somente se, um arco $f(u)$ incide em $f(v)$ em $H$.

Contanto que a restrição citada seja levada em consideração, não há nenhuma forma pré-definida de construção dos grafos-chave de uma imagem. No âmbito deste trabalho, definiu-se que os grafoschave são construídos sobre um conjunto de 3 vértices, com a adição de 3 arcos dirigidos formando um ciclo. Mais detalhes sobre a razão desta escolha serão discutidas na Seção 3.4.

\subsection{Fases de indexação e busca}

O método de detecção de objetos por grafos-chave é dividido em duas fases principais: indexação e busca. Na primeira fase, são construídos os grafos-chave sobre as imagens modelo, bem como são calculados seus respectivos descritores. Esta fase é realizada offline, ou antes do processamento em tempo real, de forma a melhorar o desempenho durante a detecção. Os descritores obtidos dos modelos são então armazenados em uma estrutura de indexação, possibilitando que a consulta se torne muito mais eficiente e que, mesmo que a quantidade de descritores seja grande, não afete significativamente o desempenho. Neste trabalho, optou-se por utilizar a biblioteca de indexação FLANN (Muja e Lowe (2009)) para realizar esta tarefa. A biblioteca FLANN é composta por diversas formas de indexação e permite que sejam testadas e analisadas qual delas é a mais indicada para o tratamento de cada problema. A biblioteca escolhida foi a de busca baseada em árvores- $k d$ (kd-trees) (Beis e Lowe (1997)), que são estruturas eficientes para o armazenamento e busca de 
vetores de muitas dimensões.

A fase de busca é realizada online, ou em tempo real, e consiste em: primeiramente construir os grafos-chave das imagens cena, que estão sendo capturadas em tempo real. A partir dos grafos são calculados seus respectivos descritores, que por sua vez são comparados com os descritores obtidos das imagens modelos. Se a diferença entre os descritores da cena e do modelo estiver abaixo de um dado limiar, então considera-se que houve um casamento, e este modelo é adicionado à lista de objetos candidatos. Posteriormente, após realizar o casamento de todos os grafos-chave da cena, estima-se a pose (Seção 3.5) de cada um dos candidatos na cena e calcula-se a quantidade de correspondências que se adaptam corretamente à pose obtida. O melhor modelo é então obtido escolhendo aquele cuja pose satisfaz a maior quantidade de correspondências. Finalmente, caso o modelo escolhido apresente uma quantidade suficiente de correspondências, então considera-se que o objeto procurado foi detectado.

\subsection{Descritores}

Existem diversas formas de se obter descritores de grafos-chave. Uma abordagem natural seria estender a informação obtida pelo detector de pontos-chave, incorporando as informações estruturais que os grafos podem capturar. Entretanto, como o método de grafos-chave deve ser independente da escolha do detector de pontos, e como cada um desses detectores tem suas próprias peculiaridades para obtenção de seus descritores, fica muito difícil de se criar um modelo de extensão capaz de se adaptar a todos eles.

Nesse sentido, a ideia utilizada para a obtenção dos descritores dos grafos-chave foi descartar completamente os descritores dos pontos-chave e criar os dos grafos-chave baseando-se apenas nas informações dos arcos dos grafos. Os descritores de arcos são construídos calculando os perfis de intensidade sobre os arcos e aplicando-se uma Transformada de Fourier sobre o perfil obtido e armazenando alguns de seus coeficientes. As seções 3.3.1 e 3.3.2 discutem mais a fundo os passos envolvidos na construção dos descritores.

\subsubsection{Perfis de intensidade}

Perfis de intensidade (Tell e Carlsson $(2000,2002)$ ) são obtidos simplesmente tomando os valores, em tons de cinza, dos pixels que devem ser considerados. No caso dos descritores de arcos, os pixels escolhidos são aqueles que estão presentes ao longo do arco na imagem sobre a qual o grafo-chave foi construído. A Figura 3.2 mostra um exemplo de um arco e seu perfil de intensidade.

Perfis de intensidade são alternativas interessantes para a descrição de imagens, pois apresentam algumas características importantes:

- Robustez à rotação: assumindo que os mesmo pontos sejam detectados nas diferentes imagens rotacionadas, os perfis de intensidade dos arcos que ligam tais pontos não sofrem alterações;

- Robustez à escala: apesar de que originalmente os perfis de intensidade não ofereçam nenhuma informação para o tratamento da variação de escala, os arcos dos grafos-chave têm um conceito bem definido de comprimento, que pode ser utilizado para escalar os perfis adequadamente;

- Simplicidade de descrição: como perfis de intensidade são calculados com base em um simples segmento de reta e, portanto, são unidimensionais, seus descritores podem ser eficientemente 


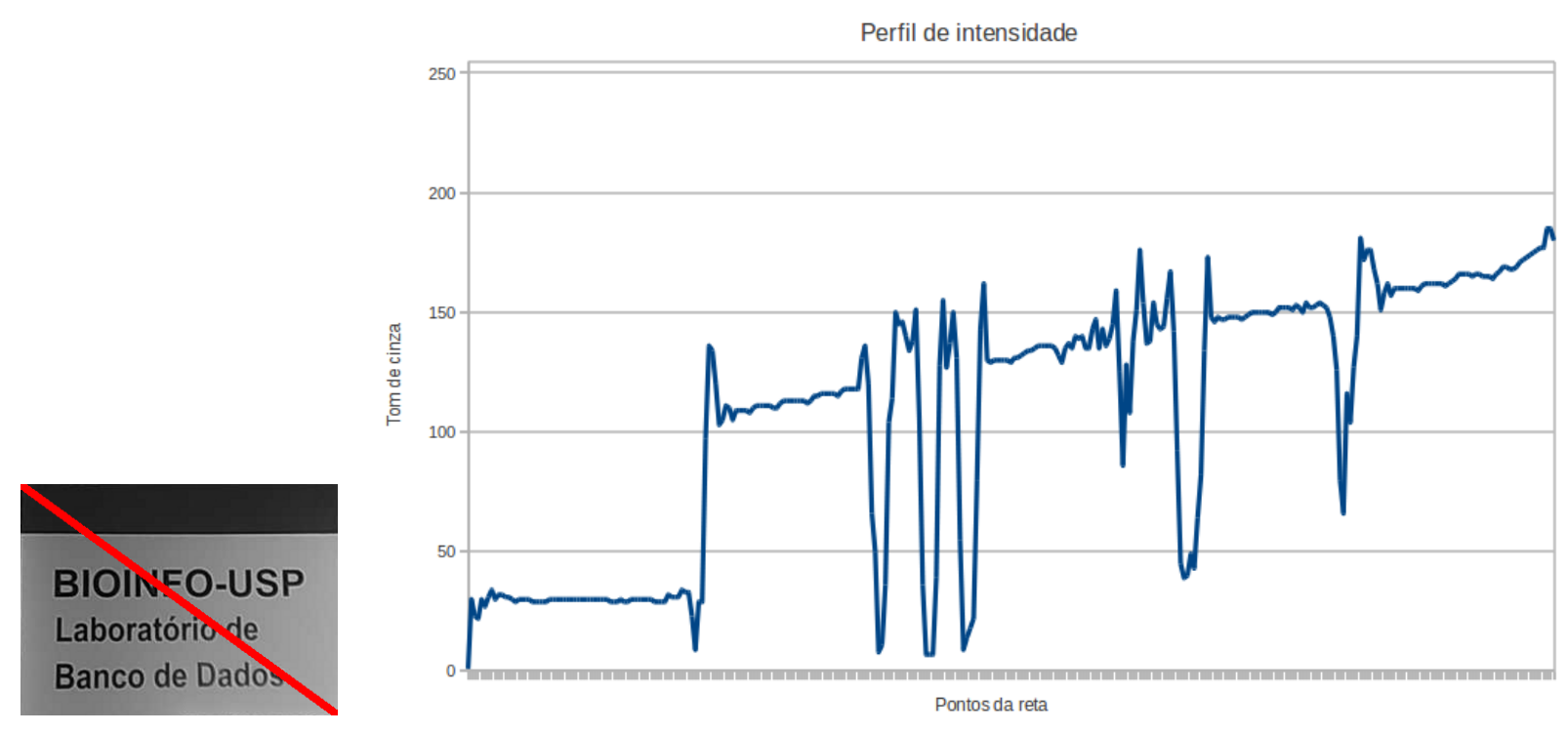

Figura 3.2: O gráfico à direita mostra o perfil de intensidade da reta diagonal marcada na placa à esquerda.

representados de forma sucinta, bem como podem ser obtidos de forma muito eficiente, usando o algoritmo de Bresenham (1965).

Existem, entretanto, algumas restrições. Perfis de intensidade impõem a restrição de planaridade sobre o objeto e não são robustos a transformações de perspectiva. Mas como será visto mais a fundo na Seção 3.4, os grafos-chave oferecem formas eficientes de lidar com tais restrições.

\subsubsection{Transformada de Fourier}

A Transformada de Fourier (Gonzalez e Woods (2008)) é um método de representação de funções que permite que elas sejam decompostas em suas componentes sinusoidais. A transformada tem diversas aplicações em muitas áreas, sendo, em particular, muito importante para o tratamento de imagens. Geralmente, o termo Transformada de Fourier se refere à sua versão para funções contínuas, que pode representar qualquer função integrável. Entretanto, para o tratamento de imagens, é necessário utilizar, sua versão discreta, ou amostrada, que é dada por:

$$
F(k)=\sum_{x=0}^{n-1} f(x) e^{-\frac{2 \pi i}{n} k x}
$$

considerando:

$i$ : a unidade imaginária

$f(x)$ : o valor do pixel em $x$

$F(k)$ : o $k$-ésimo coeficiente imaginário de Fourier

A transformada de Fourier foi calculada utilizando-se a biblioteca FFTW ${ }^{1}$ e é usada neste trabalho para descrever os arcos dos grafos-chave a partir dos dados obtidos do perfil de intensidade. O descritor adotado foi baseado nos trabalhos de Tell e Carlsson (2000, 2002), e sua construção pode ser descrita pelos seguintes passos:

1. Calcule a transformada de Fourier do perfil de intensidade;

\footnotetext{
${ }^{1}$ http://www.fftw.org/
} 
2. Armazene os componentes reais $r_{j}$ e imaginários $i_{j}$ de seus segundo, terceiro e quarto coeficientes num vetor;

3. Normalize o vetor, dividindo cada elemento por $s$, sendo $s=\sqrt{\sum_{x=1}^{3}\left(a_{x}^{2}+b_{x}^{2}\right)}$.

O primeiro coeficiente pode ser interpretado como o valor médio dos pixels da imagem. Assim, desconsiderando este coeficiente, pode-se obter um descritor mais robusto a variações aditivas de iluminação. Além disso, ao se normalizar seus coeficientes, obtém-se também robustez a variações de escala e de iluminação multiplicativa. A escolha de armazenar três coeficientes foi definida empiricamente, apresentando um bom resultado de discriminação enquanto mantém a baixa dimensionalidade do vetor de descrição.

\subsection{Restrições}

Um fato importante que deve ser considerado quando se trabalha com grafos-chave é que a quantidade de grafos que podem ser gerados a partir de um conjunto de pontos é exponencial. Nesse sentido, muitas vezes faz-se necessário aplicar algumas restrições para a geração de grafoschave, de forma a permitir que o problema seja tratado em tempo real. Entretanto, como será discutido nesta seção, os grafos naturalmente apresentam algumas características interessantes que podem ser exploradas para restringir sua geração de forma eficiente.

\subsubsection{Restrições geométricas}

Uma restrição simples e bastante intuitiva que pode ser utilizada é considerar a distância existente entre dois pontos-chave antes de se gerar um arco entre eles. Ou seja, caso os pontos estejam muito próximos, ou muito distantes, pode não ser interessante que ambos sejam adicionados no mesmo grafo-chave. A razão para tanto é simples: caso os pontos sejam muito próximos entre si, o arco gerado entre tais pontos será muito curto e, portanto, seu descritor será muito pobre, o que pode acabar por atrapalhar no processo de casamento de grafos-chave. Por outro lado, descartar arcos muito longos também pode ser interessante para restringir a quantidade de grafos gerados. Além disso, a remoção de arcos longos também contribui para contornar as restrições impostas pelos perfis de intensidade. Isso ocorre pois, ao se restringir o tamanho dos arcos, os grafos-chave gerados tornam-se mais restritos a situações locais, que têm uma maior probabilidade de respeitar a restrição de planaridade, bem como são menos impactadas pelas transformações perspectivas. A medida de proximidade utilizada pode variar, mas no âmbito deste trabalho foi escolhida a distância de Chebyshev onde, dados pois pontos $\left(x_{1}, y_{1}\right)$ e $\left(x_{2}, y_{2}\right)$, é definida por:

$$
\max \left\{\left|x_{2}-x_{1}\right|,\left|y_{2}-y_{1}\right|\right\}
$$

A distância de Chebyshev é muito simples de se calcular e apresenta bons resultados para o problema tratado. O intervalo ideal de tamanhos de arcos varia de acordo com o problema tratado, bem como com o tamanho das imagens utilizadas. No caso deste trabalho, por meio de testes empíricos, verificou-se que grafos-chave com arcos de tamanho entre 10 e 100 pixels para a imagem modeloa e de 10 a 1000 pixels para a cena apresentavam bons resultados. 

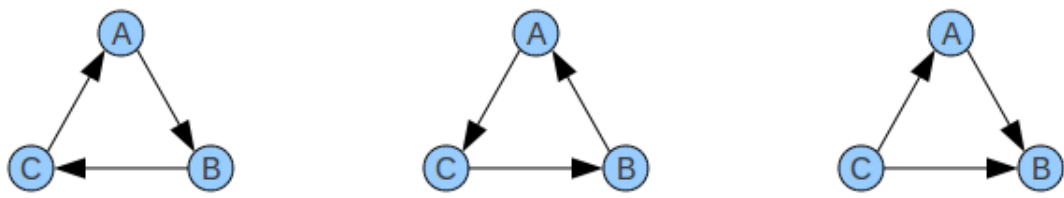

Figura 3.3: Diferentes formas de adição de arcos sobre 3 vértices. A primeira figura mostra um grafo-chave horário, enquanto que a segunda mostra um grafo-chave anti-horário. A última figura mostra um grafo-chave que não é considerado nem horário ou anti-horário.

Outra característica interessante que pode ser explorada, é o sentido dos arcos gerados para cada grafo-chave. Levando isso em consideração, é possível definir, por exemplo, que todos os grafoschave tenham seus arcos criados sempre no sentido horário que, por simplicidade, chamaremos de grafo-chave horário. De forma análoga, um grafo-chave cujos arcos estejam definidos em sentido anti-horário será chamado de grafo-chave anti-horário. Para entender melhor o conceito de um grafo-chave horário, considere 3 vértices $v_{1}, v_{2}$ e $v_{3}$ em $R^{2}$, não colineares. Podemos dizer que os arcos para estes 3 vértices estão no sentido horário se o caminho definido pelos arcos percorre os vértices somente no sentido horário. A Figura 3.3 mostra alguns exemplos de diferentes disposições de arcos sobre 3 vértices pré-definidos e um exemplo de grafo-chave horário.

A restrição de sentido horário pode ser verificada rapidamente calculando-se o produto vetorial do grafo-chave. Além disso, a utilização desta restrição não impacta negativamente na detecção de objetos, a menos que seja necessário considerar o espelhamento do objeto procurado, i.e., a inversão do sentido do objeto, o que não é o caso para o tratamento do problema proposto.

É claro que, para alguns grafos, nem sempre faz sentido o conceito de arcos horários ou antihorários, pois para grafos com mais vértices e arcos, pode não ser possível definir, de maneira não-ambígua, o conceito de sentido horário. Por esta e outra razão que será apresentada a seguir, optou-se por trabalhar com grafos-chave construídos por 3 vértices e 3 arcos, ou simplesmente um ciclo de tamanho 3. Neste caso, é muito simples e intuitivo de se imaginar quais grafos-chave são horários.

\subsubsection{Planaridade de grafos-chave}

Ainda que as restrições geométricas diminuam um pouco a quantidade de grafos-chave que podem ser gerados a partir de um conjunto de pontos, elas não diminuem a complexidade assintótica do problema. Neste sentido, as restrições geométricas são opções válidas e interessantes para serem aplicadas na fase de indexação da detecção por grafos-chave, i.e., quando são construídas as representações dos modelos, que são realizadas antes do processamento em tempo real e que podem ser armazenadas numa estrutura de indexação. Entretanto, para o tratamento da imagem da cena, que deve ser capturada diretamente de uma sequência de vídeo durante a execução em tempo real, as restrições geométricas podem não ser suficientes para se obter o desempenho desejado.

Uma forma de se restringir ainda mais a geração dos grafos-chave é fazer com que a combinação de todos os grafos definidos sobre a imagem seja planar. Para tanto, pode-se utilizar o método da Triangulação de Delaunay (de Berg et al. (2008)). Como mostrado pelos autores, a aplicação da triangulação faz com que o grafo definido sobre toda a imagem seja planar e que, neste caso, a 
quantidade de arcos é linear na quantidade de pontos utilizados, o que torna o problema tratável. A triangulação pode ser implementada de forma eficiente usando o algoritmo de Fortune (1986) e, posteriormente, os grafos-chave podem então ser extraídos da triangulação obtida. O uso da triangulação para geração dos grafos-chave da imagem é outra das razões pela qual optou-se pela utilização de grafos-chave triangulares. Neste caso, os grafos-chave são obtidos de forma única diretamente do esquema de triangulação aplicado.

\subsubsection{Restrições adicionais para dispositivos móveis}

Devido ao seu tamanho reduzido e da necessidade de gastar pouca energia, dispositivos móveis dispõem de recursos muito mais limitados que um computador comum. Neste sentido, a fim de tornar o processamento em tempo real viável nestes aparelhos, pode ser necessário restringir ainda mais a deteç̧ão. Nesta seção serão descritas algumas das restrições implementadas para viabilizar todo o processo no dispositivo móvel.

Um fator que impacta fortemente no desempenho do aplicativo é o tamanho das imagens usadas tanto para o modelo como para a cena. Isso se dá principalmente por duas razões: primeiro, mesmo contando com a robustez a mudanças de escala, devido à presença de ruído e ao fato de uma imagem corresponder a uma representação discretizada do espaço, é inevitável que o uso de imagens maiores gere uma quantidade maior de pontos-chave e, portanto, também de grafos-chave. Segundo, a quantidade de memória necessária para armazenar todas as imagens pode se tornar inviável num dispositivo móvel. Neste sentido, optou-se por utilizar modelos com um comprimento de no máximo 500 pixels no lado mais longo. As imagens da cena, capturadas pela câmera do dispositivo, foram mantidas no tamanho padrão de captura de 640x480. De acordo com testes realizados, essa configuração permite que um relativo bom desempenho seja obtido considerando o tempo necessário para o processamento da imagem em relação à taxa de detecção de placas na imagem.

Porém, além de usar imagens menores, faz-se necessário restringir a quantidade de pontos-chave detectados a cada imagem. Uma forma simples de se obter tal resultado é simplesmente impondo uma quantidade máxima de pontos desejados e descartando os pontos restantes. Entretanto, se os pontos forem descartados indiscriminadamente, não há qualquer garantia de que os melhores pontos-chave serão mantidos. Para contornar este problema, é possível impor alguma ordenação de relevância e descartar os pontos menos significativos. Este último método, porém, necessita de processamento adicional para realizar a ordenação dos pontos, que pode acabar por impactar no desempenho do aplicativo. Por esta razão, neste trabalho, optou-se por limitar a geração dos pontoschave simplesmente configurando os parâmetros do próprio detector. Se, por um lado, tal abordagem claramente oferece a vantagem de não depender de um pós-processamento dos pontos encontrados, por outro, pode também apresentar algumas dificuldades, visto que não é possível garantir nenhum limite absoluto tanto inferior quanto superior para a quantidade de pontos detectados em cada imagem. Neste caso, porém, as restrições de tamanho da imagem mencionadas contribuem para que os resultados em geral sejam bem comportados. De acordo com testes empíricos realizados, verificou-se que uma configuração que, em geral, não detecta mais que 70 pontos-chave é ideal para a aplicação.

Outra restrição adotada, foi a da descrição das imagens modelo, de forma que a quantidade de grafos-chave detectados fosse linear na quantidade de pontos-chave. Tal decisão foi tomada pois, apesar de tais imagens poderem ser pré-processadas, a necessidade de armazenar a estrutura de 
indexação de seus descritores mostrou-se problemática. Como a princípio cada imagem era descrita da forma mais rica possível, a quantidade de descritores indexados crescia rapidamente com a adição de novos modelos. Apesar de a estrutura eficiente da indexação permitir que a busca continuasse eficiente, a quantidade de memória necessária para armazenar os índices rapidamente excedeu as capacidade reduzidas do dispositivo, impactando fortemente no desempenho. Por esta razão, optouse por também obter os grafos-chave dos modelos a partir da triangulação de Delaunay. Entretanto, além de extrair os arcos da triangulação regular considerando todos os pontos-chave, foram também criadas mais 10 triangulações, cada uma construída sobre metade dos pontos detectados escolhidos aleatoriamente. Essa abordagem permitiu que a quantidade de descritores gerados fosse significativamente reduzida, ao mesmo tempo em que um certo nível de robustez fosse mantido.

Finalmente, para melhorar ainda mais o desempenho do método, foram utilizadas também algumas heurísticas para a escolha do melhor modelo a cada detecção. Primeiramente, baseando-se no aspecto temporal de uma sequência de vídeo, sempre que um objeto já houvesse sido detectado no quadro anterior da sequência de vídeo, esse objeto era escolhido como uma primeira alternativa de casamento no quadro posterior. Se no novo quadro fossem detectados pelo menos $50 \%$ da quantidade de casamentos do quadro anterior, então o modelo era aceito diretamente sem verificar os demais. Ainda que esta abordagem pareça degradativa, os resultados obtidos mostraram-se bastante favoráveis, contribuindo para a redução do tempo de processamento, enquanto mantinha uma boa taxa de deteções positivas. De fato, mesmo na ausência de um modelo a priori, a busca exaustiva pelo melhor modelo foi evitada. Como os grafos-chave se mostraram altamente discriminativos, obtendo um alta taxa de deteç̧ões positivas, optou-se também por simplesmente terminar a busca de modelos quando o primeiro casamento fosse encontrado, sem verificar se havia um melhor candidato.

\subsection{Estimativa de pose}

A estimativa de pose é realizada de forma similar à utilizada no métodos de detecção por pontoschave tradicionais. Sucintamente, ela consiste em verificar as correspondências encontradas entre as duas imagens e calcular uma matriz de transformação $H$ (homografia) dos pontos de cada imagem, tal que:

$$
x^{\prime}=H x
$$

sendo $x$ as coordenadas afins de um pixel em uma imagem, e $x^{\prime}$ as coordenadas de sua projeção na outra imagem.

Como pode ser visto em Hartley e Zisserman (2004), o sistema resultante pode ser resolvido de forma única se forem utilizadas pelo menos 4 correspondências de pontos distintos e não-colineares. Num caso ideal, então, bastaria tomar quaisquer 4 correspondências entre as duas imagens e utilizálas para calcular a matriz desejada. Entretanto, na prática, nem todas as correspondências encontradas apresentam resultados confiáveis, principalmente devido à existência de erros nas correspondências encontradas, que são bastante comuns deste tipo de abordagem. Tal fato ocorre pois, em muitos casos, a região considerada para o casamento é ambígua, i.e., existem diversas regiões na mesma imagem que podem ser descritas da mesma forma.

Decidir se uma dada correspondência é correta pode ser uma tarefa difícil e computacionalmente 
cara. Por esta razão, uma solução prática e amplamente utilizada é manter todas as correspondências encontradas, tanto as corretas quanto as errôneas, e encontrar as melhores correspondências com o auxílio de um método estatístico de ajuste, como, por exemplo, o RANSAC.

\subsubsection{RANSAC}

O RANSAC (Fischler e Bolles (1981)) é um algoritmo de ajuste iterativo que se aproveita da aleatoriedade para realizar uma boa escolha de parâmetros de forma robusta. Ele é robusto no sentido de que é capaz de encontrar um bom resultado mesmo com a presença de diversos outliers no conjunto testado. Por sua característica aleatória, o RANSAC é um algoritmo não-determinístico, que pode produzir um bom resultado apenas com certa probabilidade, que aumenta à medida em que se permite mais iterações no algoritmo. De forma geral, o algoritmo RANSAC aplicado ao problema de estimativa de pose em questão pode ser descrito pelo seguinte pseudo-código:

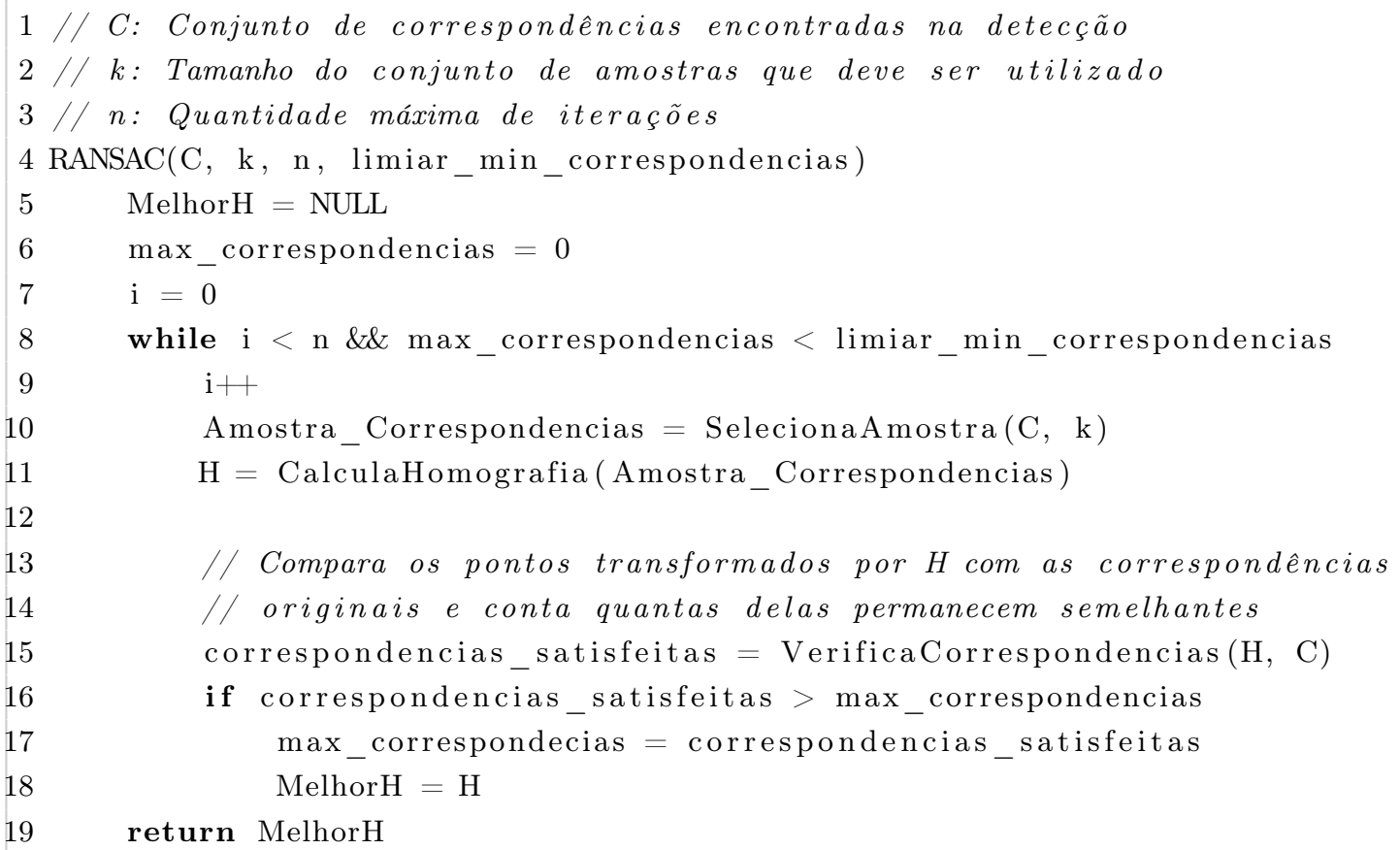

A escolha da quantidade mínima de correspondências adequadas para se aceitar o resultado pode variar de acordo com o problema. No âmbito deste trabalho, decidiu-se aceitar a homografia quando pelo menos 3 grafos-chave fossem corretamente correspondidos. Os demais parâmetros, $k$ e $n$, por outro lado, podem ser escolhidos de forma mais precisa.

O valor de $k$, ou o tamanho do conjunto de amostras escolhidas do conjunto de correspondências totais, deve ser suficiente para que a homografia seja calculada de forma única que, como já citado, deve ser de pelo menos 4 pontos. Porém, como estamos trabalhando com correspondências de grafoschave de 3 vértices, ao invés de pontos-chave individuais, escolhemos $k$ como dois grafos-chave distintos. Como pode ser visto na Figura 3.4, tal escolha garante que pelo menos 4 vértices distintos sejam escolhidos. Além disso, pela propriedade triangular dos grafos-chave escolhidos, garante-se que os 4 pontos tomados nunca sejam colineares, eliminando a necessidade de uma verificação adicional.

Finalmente, o parâmetro $n$, ou a quantidade máxima de iterações permitidas para o algoritmo convergir, deve ser escolhida de modo que seja grande o suficiente para permitir que na maior parte dos casos a convergência seja possível, mas também deve limitar o tempo de busca de forma razoável. 

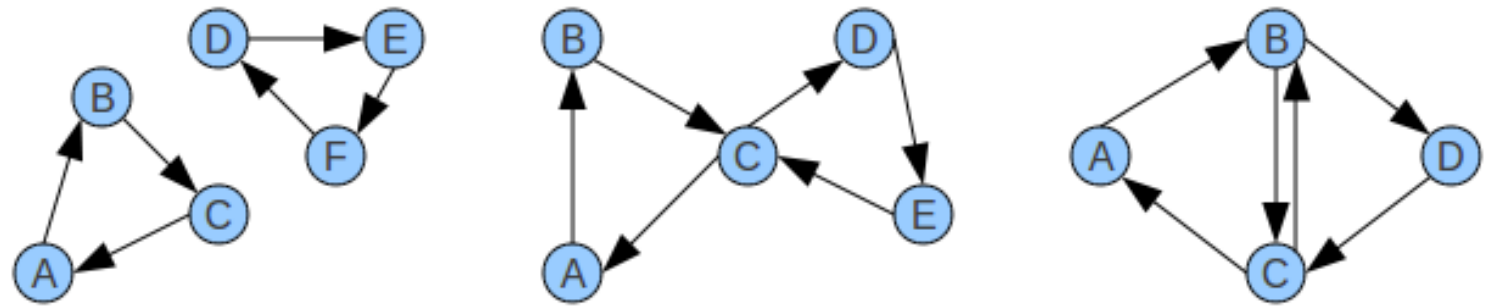

Figura 3.4: Possiveis pontos (vértices) obtidos pela escolha de dois grafos-chave.

A convergência neste caso é obtida quando um bom conjunto de correspondências é encontrado. Uma boa escolha de $n$ pode ser calculada caso estejam à disposição algumas informações adicionais, como será apresentado a seguir.

Como definido no pseudo-código, seja $C$ o conjunto com todas as correspondências encontradas durante a detecção e $C^{\prime}$ o subconjunto de $C$ que representa as amostras escolhidas numa iteração do RANSAC. Como já definido, $\left|C^{\prime}\right|=k$, sendo $\left|C^{\prime}\right|$ a cardinalidade do conjunto $C^{\prime}$. Seja $I \subseteq C$ o conjunto somente de inliers de $C$. É razoável assumirmos que, se em alguma iteração do algoritmo, valer que $C^{\prime} \subseteq I$, então houve convergência e, portanto, a execução é concluída. Seja $q$ a chance do algoritmo convergir em algum momento, i.e., a chance de obtermos uma resposta desejada.

Para obtermos $q$, primeiramente é necessário calcularmos $P\left(C^{\prime} \subseteq I\right)$, em cada iteração, sendo $P$ a probabilidade do evento ocorrer. Para tanto, seja $p=\frac{|I|}{|C|}$ a probabilidade de que um inlier seja escolhido. Caso os elementos de $C^{\prime}$ fossem escolhidos de forma independente, é fácil ver que $P\left(C^{\prime} \subseteq I\right)=p^{k}$. Entretanto, este não é caso, já que uma vez que uma correspondência é utilizada, ela não retorna mais ao conjunto $C$. Esse é um problema clássico de sorteio sem reposição. Assim, a probabilidade desejada pode ser calculada pela fórmula da distribuição hipergeométrica (Morettin e de Oliveira Bussab (2010)):

$$
P\left(C^{\prime} \subseteq I\right)=\frac{\left(\begin{array}{c}
|I| \\
k
\end{array}\right)\left(\begin{array}{c}
|C|-|I| \\
s-k
\end{array}\right)}{\left(\begin{array}{c}
|C| \\
s
\end{array}\right)}
$$

sendo $s$ a quantidade de elementos extraídos de $C$ e $k$ a quantidade deles que devem ser inliers.

No nosso problema, queremos que todos os elementos extraídos sejam inliers, então temos que $s=k$. Assim podemos simplificar a fórmula reescrevendo-a:

$$
P\left(C^{\prime} \subseteq I\right)=\frac{\left(\begin{array}{c}
|I| \\
k
\end{array}\right)}{\left(\begin{array}{c}
|C| \\
k
\end{array}\right)}
$$

A probabilidade descrita por $q$ representa a chance de, em $n$ iterações, pelo menos uma delas convergir, i.e., obtermos $C^{\prime} \subseteq I$. Esse resultado pode ser obtido subtraindo a probabilidade de, em nenhuma das $n$ iterações, o conjunto $C^{\prime}$ ser bem escolhido, da soma total das probabilidades (igual a um). Como cada iteração é um evento independente, a probabilidade de escolher um conjunto com algum outlier em todas as $n$ iterações é dado por:

$$
\left(1-\frac{\left(\begin{array}{c}
|I| \\
k
\end{array}\right)}{\left(\begin{array}{c}
|C| \\
k
\end{array}\right)}\right)^{n}
$$


E consequentemente, $q$ é obtido por:

$$
q=1-\left(1-\frac{\left(\begin{array}{c}
|I| \\
k
\end{array}\right)}{\left(\begin{array}{c}
|C| \\
k
\end{array}\right)}\right)^{n}
$$

Isolando o $n$, temos:

$$
\begin{aligned}
q-1 & =-\left(1-\frac{\left(\begin{array}{c}
|I| \\
k
\end{array}\right)}{\left(\begin{array}{c}
|C| \\
k
\end{array}\right)}\right)^{n} \\
1-q & =\left(1-\frac{\left(\begin{array}{c}
|I| \\
k
\end{array}\right)}{\left(\begin{array}{c}
|C| \\
k
\end{array}\right)}\right)^{n} \\
\log (1-q) & =\log \left(1-\frac{\left(\begin{array}{c}
|I| \\
k
\end{array}\right)}{\left(\begin{array}{c}
|C| \\
k
\end{array}\right)}\right)^{n} \\
\log (1-q) & =n \log \left(1-\frac{\left(\begin{array}{c}
|I| \\
k
\end{array}\right)}{\left(\begin{array}{c}
|C| \\
k
\end{array}\right)}\right) \\
n & =\frac{\log (1-q)}{\log \left(1-\frac{\left(\begin{array}{c}
|I| \\
k
\end{array}\right)}{\left(\begin{array}{c}
|C| \\
k
\end{array}\right)}\right)}
\end{aligned}
$$

Desta forma, o parâmetro $n$ pode ser calculado escolhendo um valor desejado $q$ de convergência. Além disso, é necessário descobrir a porcentagem de inliers existentes em $C$. Na prática, entretanto, pode ser muito difícil conhecer esse valor a princípio. Por isso, é mais comum o uso de algum tipo de aproximação razoável. Neste trabalho foi considerado $|C|=20$ uma boa estimativa para as correspondências de grafos-chave encontradas a cada quadro do vídeo. Como é muito difícil identificar os inliers ou outliers do conjunto, foi utilizada uma estimativa pessimista de que $|I|=10$. O parâmetro $k$, como já mencionado, é igual a 2 e foi escolhido $q=0.99$. Substituindo esse valores em (3.9), verifica-se que $n \approx 17$. Assim, escolheu-se trabalhar com $n=20$. 


\section{Capítulo 4}

\section{Sistema de detecção móvel}

Neste capítulo, serão apresentadas uma descrição do estudo de caso criado para a avaliação da proposta desenvolvida e a forma como o aplicativo foi implementado para realizar a detecção das placas e a estimativa de localização.

Para avaliar o desempenho do aplicativo numa situação de uso real, foram coletados dados de um ambiente interno para a formação dos conjuntos de treinamento e validação. O local escolhido foi um corredor do segundo andar do Bloco A do IME-USP, como mostrado na Figura 4.1. Deste corredor, foram escolhidas 3 placas de interesse para se detectar (Figura 4.2).

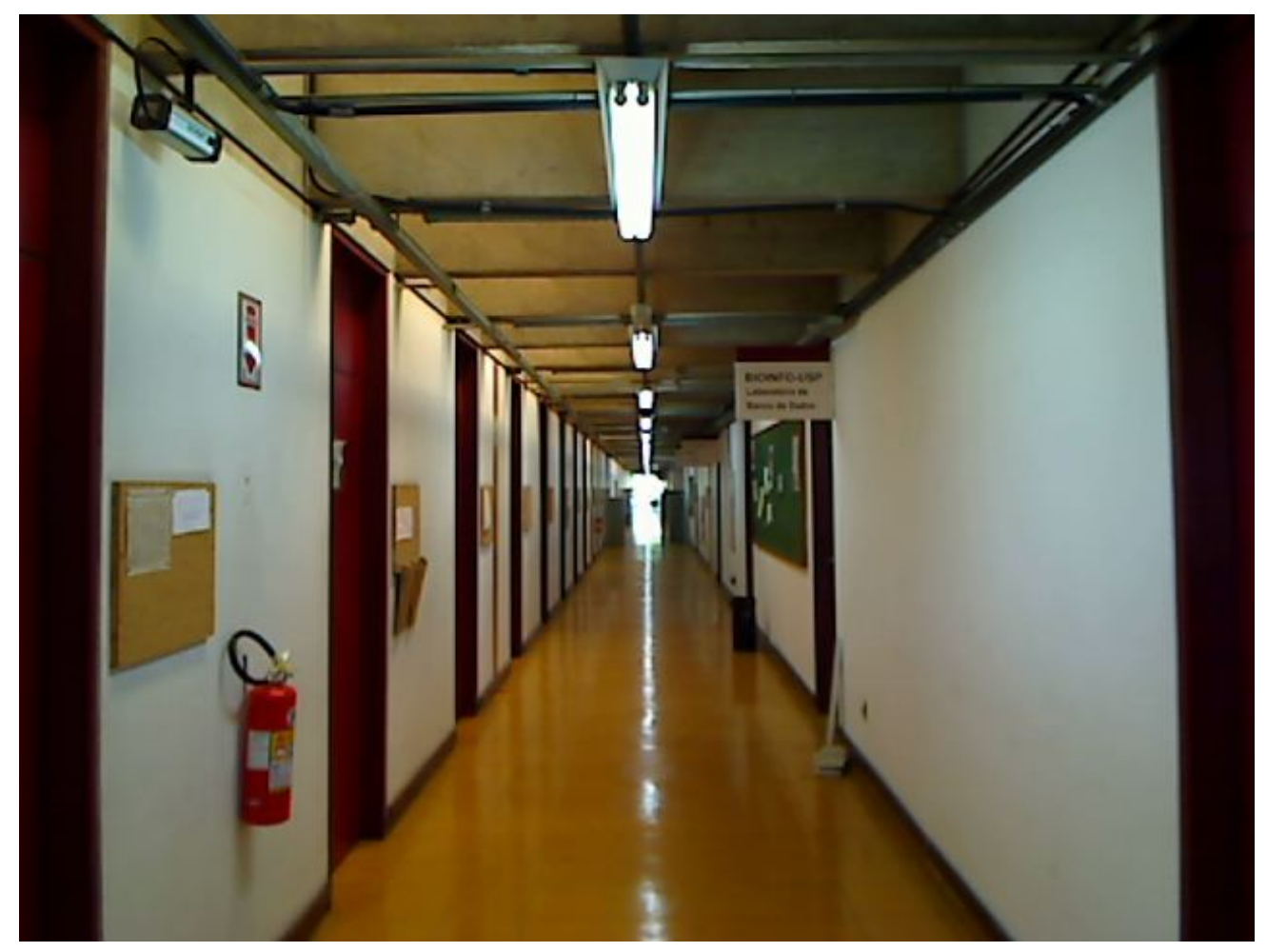

Figura 4.1: Corredor utilizado nos testes.

Em uma situação de uso real, um usuário deve se movimentar ao longo do ambiente enquanto carrega um dispositivo móvel com câmera apontando na direção que deseja se mover. O aplicativo então deve tentar detectar alguma das placas de interesse pela imagem capturada pela câmera e, a partir desse resultado, estimar a sua localização ao longo do corredor. A Figura 4.3 mostra um fluxograma de todo o processo. A seguir serão discutidos mais profundamente os detalhes da 

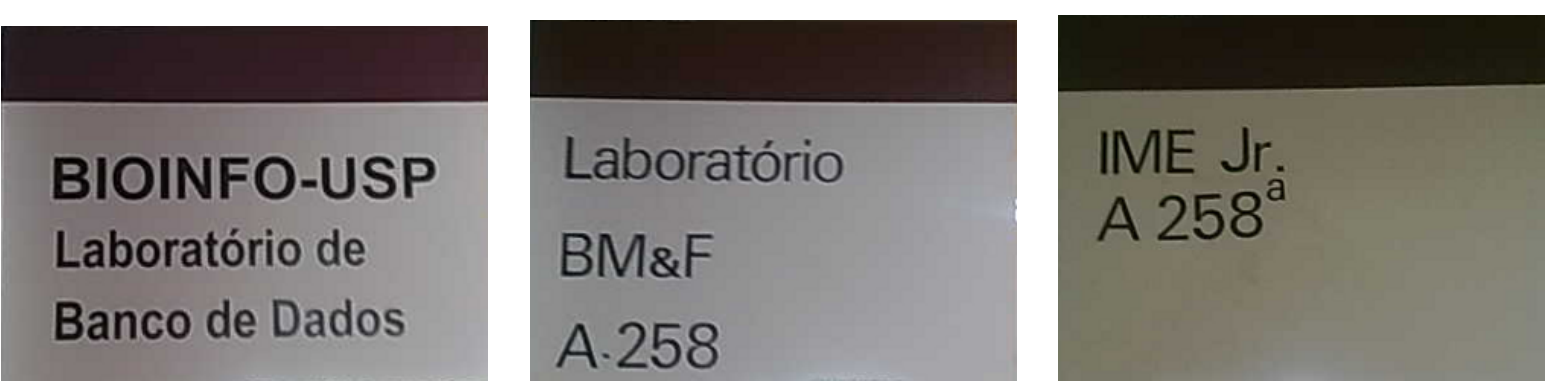

Figura 4.2: Placas a serem detectadas no corredor.

metodologia utilizada na implementação.

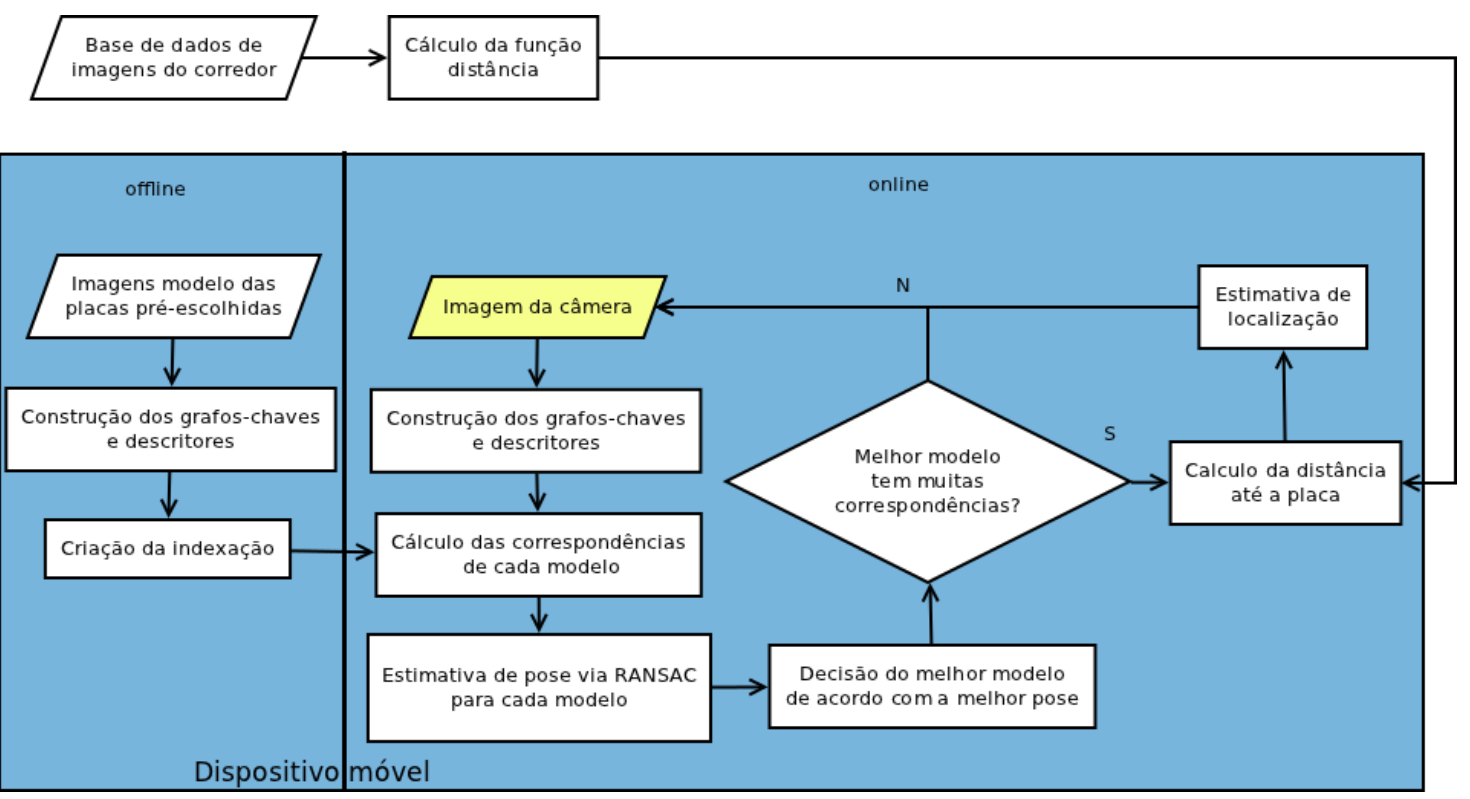

Figura 4.3: Diagrama de funcionamento do aplicativo.

\subsection{Construção da base de dados de imagens}

A estimativa de localização consiste, basicamente, em comparar algumas propriedades da placa detectada com uma base de dados de imagens pré-construída que é utilizada para se obter informações sobre o ambiente. Nesta seção e na seguinte, serão detalhados o processo de aquisição da base de dados e a sua utilização na estimativa de localização.

A base ${ }^{1}$ utilizada é um subconjunto de uma base de imagens tiradas sistematicamente ao longo do corredor escolhido sob diversos pontos de vista. Primeiramente será explicado como a base completa foi adquirida e posteriormente quais imagens particulares compõem o subconjunto de interesse. A aquisição das imagens foi realizada utilizando-se três câmeras colocadas sobre uma estrutura móvel de cerca de 1,6m de altura. A primeira câmera apontava diretamente para frente, ou na direção e sentido do movimento da estrutura, enquanto que as outras duas foram rotacionadas em ângulos de $-90^{\circ}$ e $90^{\circ}$, considerando um plano paralelo ao chão, em relação à primeira, apontando para a esquerda e direita do corredor.

\footnotetext{
${ }^{1} \mathrm{~A}$ base completa pode ser vista em http://www.vision.ime.usp.br/VisionDataset/AlbumDetail?albumId $=36$
} 
A estrutura móvel foi posicionada bem no centro do corredor e cada passo de aquisição consistiu em, com a estrutura totalmente em repouso, capturar uma imagem com todas as câmeras e mover a estrutura $60 \mathrm{~cm}$ à frente. Esse processo foi então repetido diversas vezes até se cobrir todo o corredor. Ao se atingir o final do corredor, a estrutura foi girada em $180^{\circ}$ e o processo foi repetido no sentido contrário. Entretanto, nesta fase apenas a câmera que apontava para frente foi utilizada. O intuito foi simular a existência de uma quarta câmera, apontando para trás para completar o conjunto da base de dados. A Figura 4.4 mostra um esquema do processo de captura realizado. Por simplicidade porém, diremos que cada passo de aquisição consistiu na aquisição de 4 imagens simultaneamente. Algumas imagens de exemplo do conjunto de dados podem ser vistas na Figura 4.5.
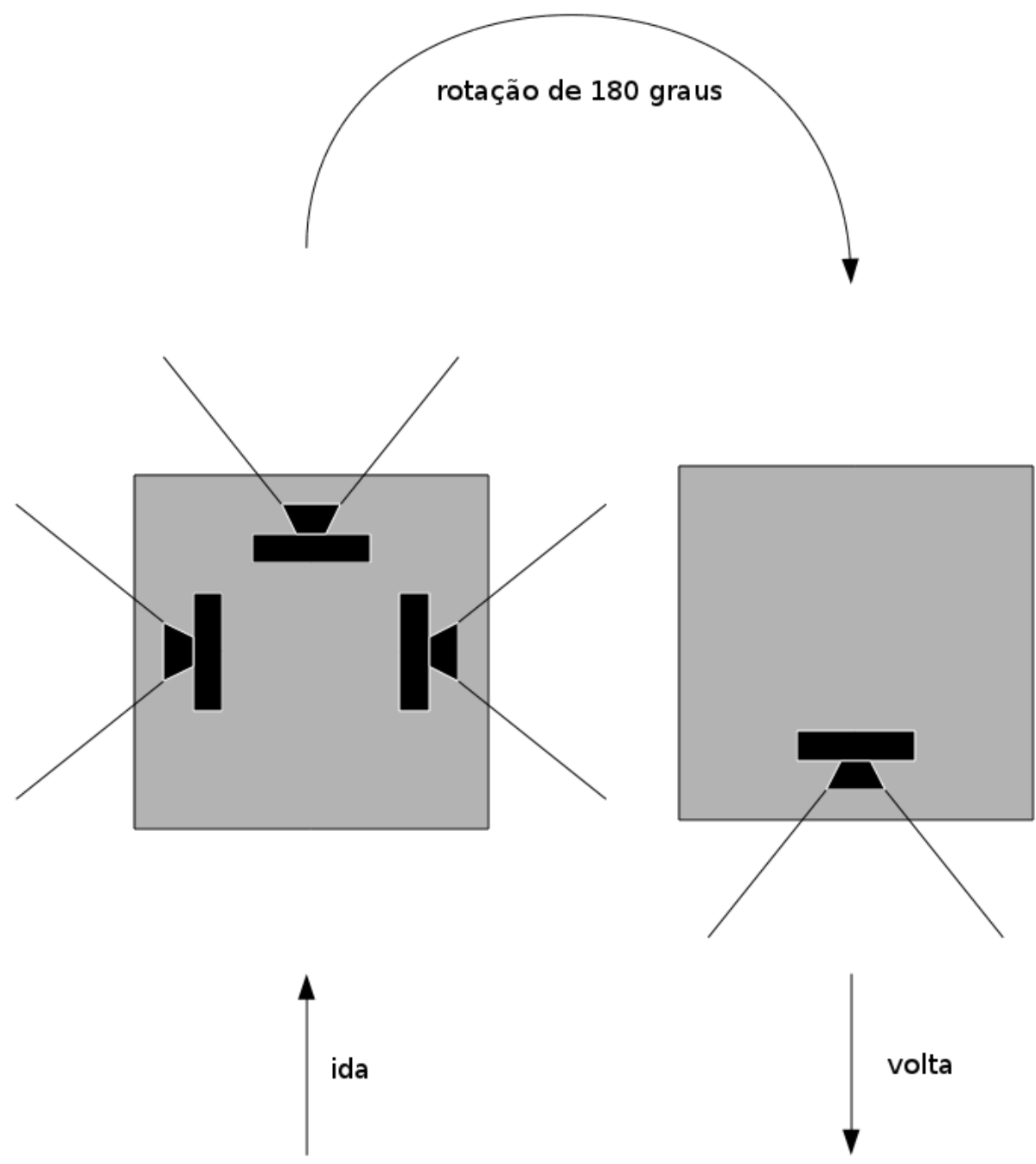

Figura 4.4: Representação esquemática do processo de captura de imagens para formação da base de dados.

Como apenas as imagens tiradas na mesma direção do movimento da estrutura móvel mostram as placas de interesse, as imagens obtidas pela câmeras laterais não foram utilizadas neste trabalho. Além disso, como a placa, tanto vista de frente como de trás é muito semelhante, optou-se por utilizar apenas as imagens da câmera da frente. Finalmente, se todo o corredor for considerado, é possível ver a existência de mais placas que não foram incluídas nos estudos. A razão de tais placas não terem sido consideradas é a existência de um grande intervalo separando a terceira placa 

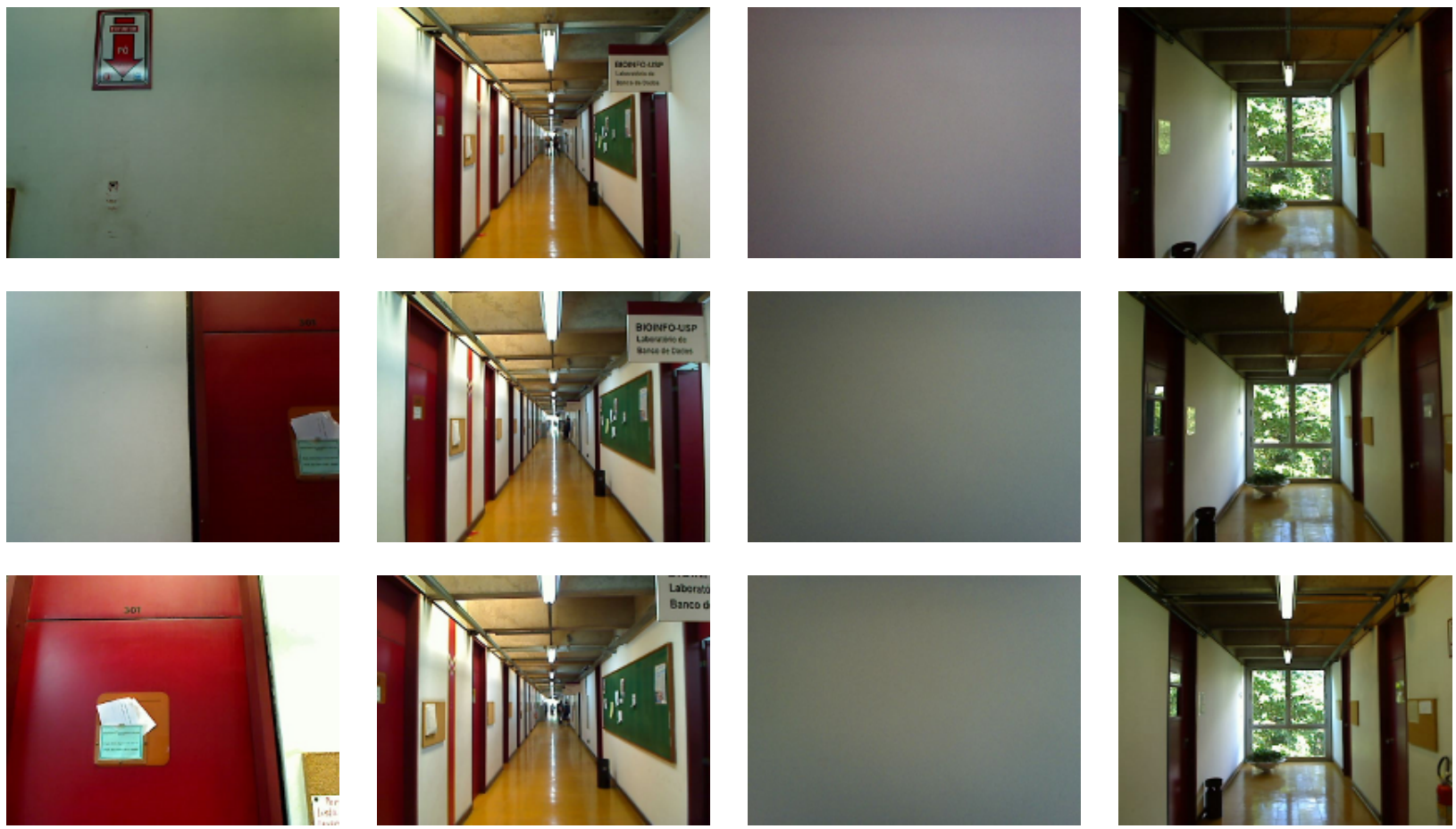

Figura 4.5: Algumas imagens da base de dados. Cada linha de imagens representa um passo de aquisição. As colunas se referem à câmera apontada para esquerda, frente, direita e trás, respectivamente.

das demais e que não é interessante para a avaliação, visto que não há o que se detectar. Neste sentido, optou-se por restringir o espaço utilizado no estudo somente a uma das alas do corredor, que contém as três placas escolhidas. Assim, o subconjunto escolhido para a avaliação consiste apenas das imagens capturadas pela câmera da frente e que mostrem alguma das 3 placas de interesse. Entretanto, como será visto na seção seguinte, a base de dados em si não é diretamente utilizada para estimativa em tempo real. Portanto, mesmo que a base fosse aumentada, não haveria impacto no desempenho da fase de localização do aplicativo.

\subsection{Método de localização}

Como o maior foco deste trabalho é a deteç̧ão correta das placas, seria interessante que o método de localização fosse capaz de dar uma estimativa relativamente precisa e confiável da posição rapidamente baseando-se na informação obtida no passo de detecção. Levando isso em consideração, optou-se por implementar a localização simplesmente comparando algumas características da placa detectada com as demais placas da base de dados. As imagens da base de dados são interessantes pois, como elas foram obtidas de forma sistemática, as posições exatas de onde cada uma delas foi capturada é conhecida. A localização pode ser obtida então simplesmente verificando qual delas é a mais similar com a imagem sendo processada.

Uma abordagem lógica e direta seria simplesmente comparar diretamente os pixels da imagem detectada com as da base de dados. Entretanto, verificar o grau de similaridade entre duas imagens desta forma não é uma tarefa tão simples. As diversas variações a que cada imagem estão expostas, tal como escala, iluminação, mudança de perspectiva, entre outras podem dificultar muito uma comparação confiável e eficaz. Por esta razão, optou-se por, ao invés de comparar a imagem dire- 
tamente, comparar somente alguma de suas características, neste caso, o seu tamanho relativo na imagem.

O tamanho, neste caso, refere-se à área da placa calculada em pixels. Na realidade, para tornar a comparação invariante à resolução de cada imagem, o valor a ser comparado não é diretamente a área da placa, mas sim a razão $r$ obtida pela divisão da área da placa pela área total da imagem. A estimativa de localização consiste então em utilizar a razão $r$ da imagem sendo processada e verificar qual das imagens da base tem a razão mais similar. A Figura 4.6 mostra algumas imagens da base de dados, suas razões $r$ e a distância $d$ medida em centímetros, entre a placa e a posição de onde a imagem foi obtida em cada caso. A posição do usuário pode ser dada somando a distância $d$ à posição da placa (fixa e conhecida) no corredor.

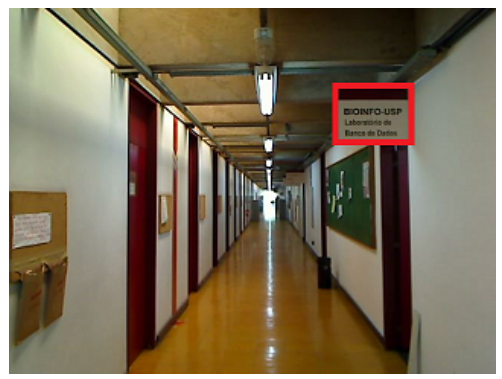

(a) $r=0.024 ; d=330 \mathrm{~cm}$

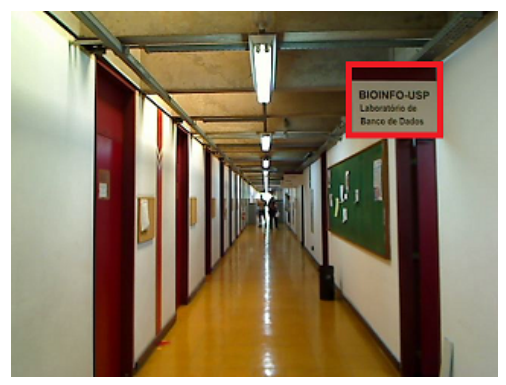

(b) $r=0.035 ; d=270 \mathrm{~cm}$

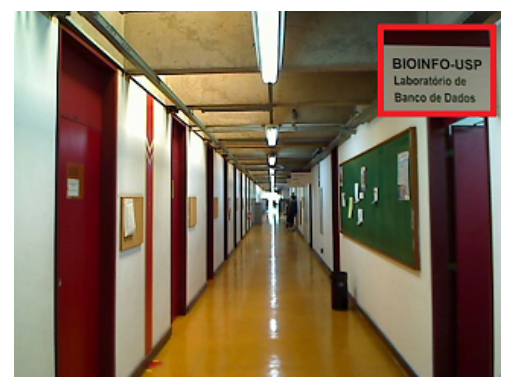

(c) $r=0.058 ; d=210 \mathrm{~cm}$

Figura 4.6: Exemplos de imagens e a razão do tamanho da placa pelo tamanho total.

Usando as imagens da base de dados como amostras e representando-as num gráfico, obtém-se os pontos mostrados na Figura 4.7. A partir de tais pontos amostrais, é possível aplicar uma forma de aproximação, como o método dos mínimos quadrados, obtendo uma função contínua que permite a estimativa de localização de forma mais precisa (ilustrada pela linha na figura) e que pode ser obtida diretamente usando apenas a razão $r$ calculada após a detecção.

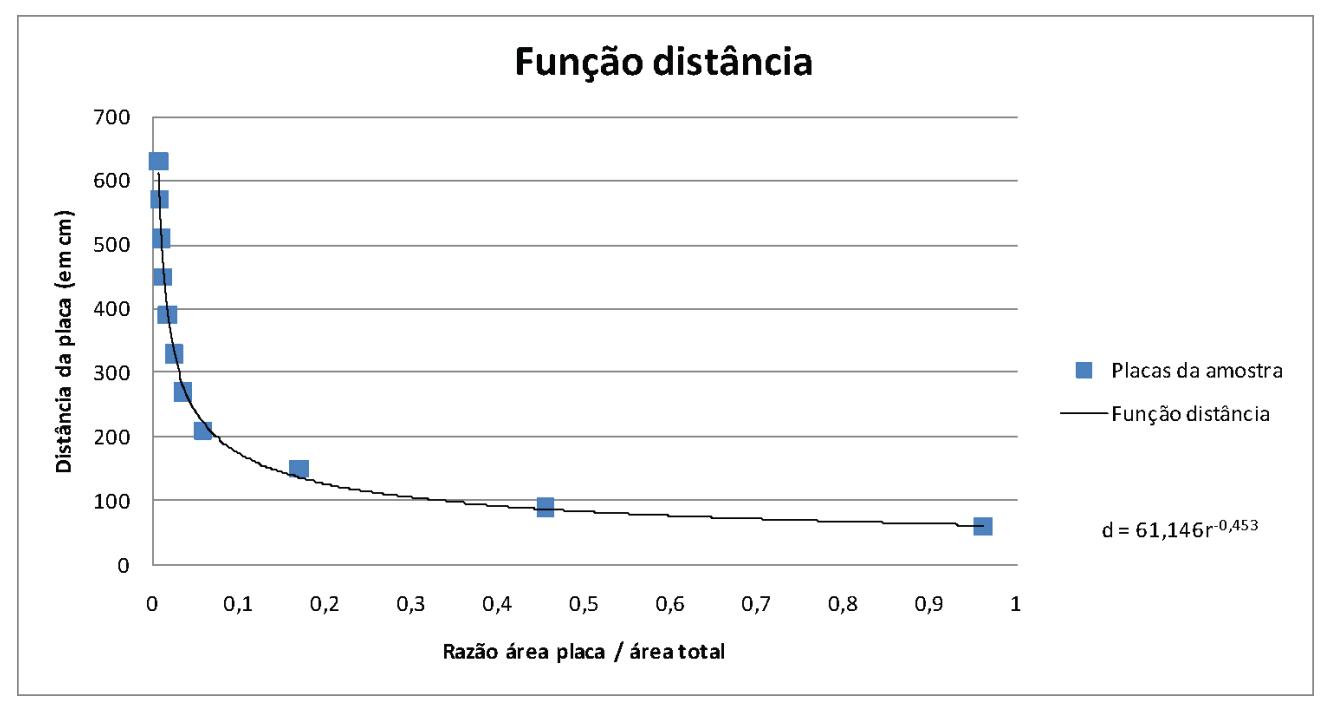

Figura 4.7: Função distância obtida por meio da avaliação das imagens da base.

Apesar de simples, este método é suficiente para o problema tratado. Além disso, o tamanho da placa pode ser obtido imediatamente como resultado da detecção, o que torna esta abordagem muito eficiente. 


\section{Capítulo 5}

\section{Resultados}

Neste capítulo, são apresentados os resultados experimentais obtidos com a utilização do aplicativo no corredor mostrado na Figura 4.1. Os resultados foram avaliados tanto em relação à precisão e robustez da deteç̧ão das placas, quanto ao desempenho em relação ao tempo decorrido para realizar o processamento do vídeo sendo capturado em tempo real. Além do resultado da deteç̧ão, foi avaliado também a precisão do método de localização.

As seções a seguir mostram os resultados obtidos para cada um dos quesitos citados. Os vídeos dos resultados aqui apresentados podem ser baixados de www.vision.ime.usp.br/ henriquem87/ mestrado/dissertacao/videos.

$\mathrm{O}$ aplicativo foi desenvolvido utilizando-se a linguagem $\mathrm{C}++$ em conjunto com a biblioteca de visão computacional OpenCV ${ }^{1}$. O dispositivo móvel escolhido foi um aparelho celular Nokia®N900 equipado com um processador ARM® Cortex $^{\mathrm{TM}} \mathrm{A} 8600 \mathrm{Mhz}$ e $256 \mathrm{MB}$ de memória RAM. Este aparelho utiliza o sistema operacional Maemo 5, baseado na distribuição Debian do Linux.

As imagens são capturadas em tempo real pela câmera do dispositivo na resolução de 640x480 pixels. Essas imagens são então imediatamente processadas para se detectar as placas de interesse e estimar a localização do usuário no ambiente. A Figura 5.1 mostra a interface gráfica (GUI) do aplicativo que é apresentada ao usuário enquanto ele navega pelo ambiente.

\subsection{Detecção das placas}

A detecção da placa é o aspecto principal do aplicativo desenvolvido, pois é a partir desta informação que é possível realizar a estimativa de localização no ambiente. Neste sentido, é importante que a placa seja detectada de forma precisa, i.e., sua pose seja estimada corretamente. Além da precisão, o método de detecção deve também oferecer certa robustez a variações de escala, rotação e oclusão parcial do objeto na cena. Finalmente, tudo isso deve ser obtido mantendo o tempo de execução dentro de limites aceitáveis para se obter uma resposta em tempo real. Nas subseções a seguir serão apresentados os resultados relativos à fase de detecção do aplicativo.

Apenas para obter um parâmetro de referência, todos os testes foram avaliados também utilizando um método de casamento de pontos-chave tradicional, sem a construção de grafos-chave. Para tanto, utilizou-se o mesmo detector MSER para se obter o conjunto de pontos-chave, e foram escolhidos descritores SURF para representar cada ponto. É importante ressaltar que o uso do detector

\footnotetext{
${ }^{1}$ http://opencv.willowgarage.com/wiki/
} 


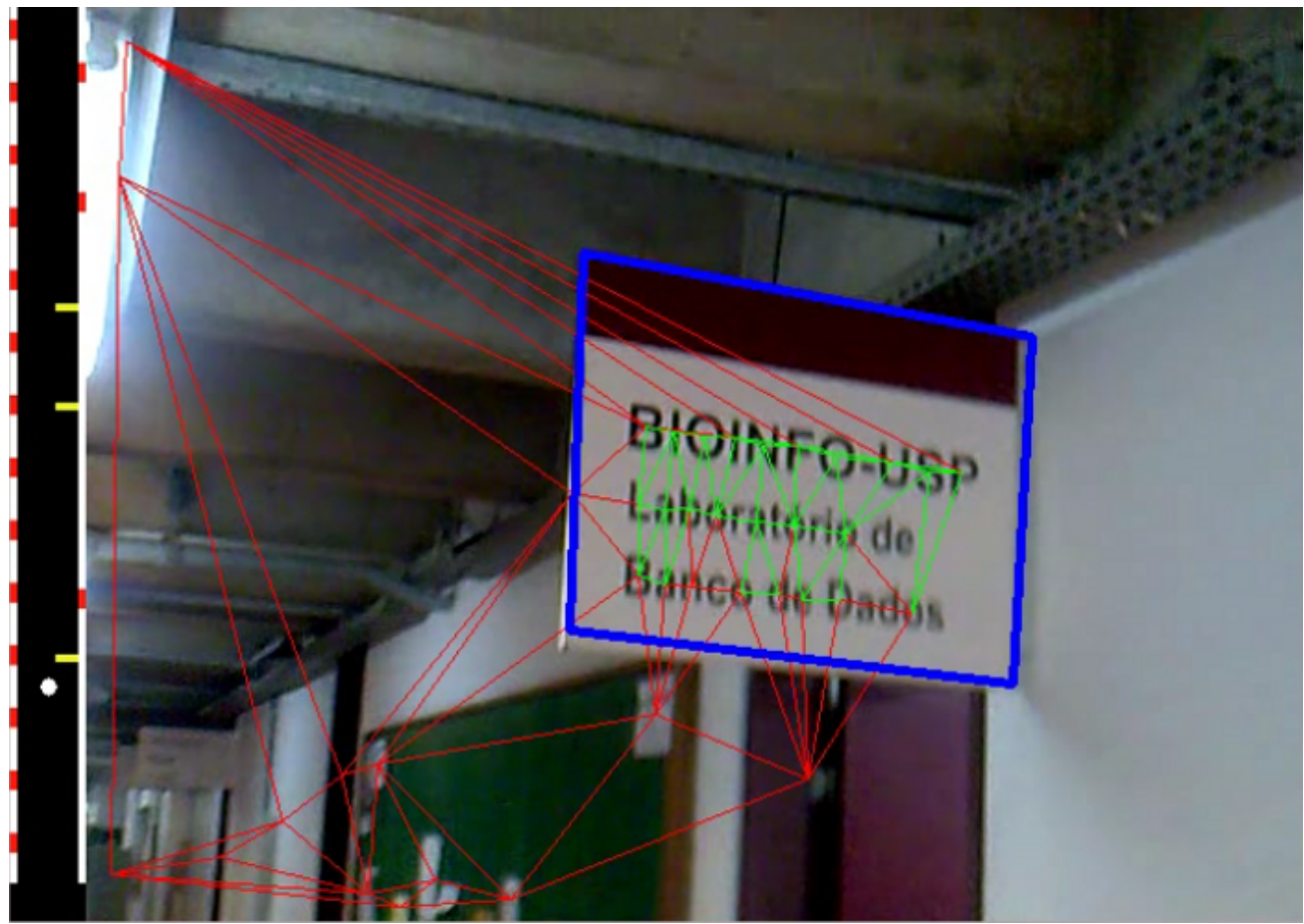

Figura 5.1: Interface gráfica do dispositivo. Do lado direito, é mostrada a imagem sendo capturada pela câmera, bem como seus grafos-chave calculados. Os triângulos verdes indicam os grafos-chave que foram correspondidos e a borda azul ao redor da placa mostra a pose estimada a partir das correspondências. O lado esquerdo mostra um mapa esquemático do corredor. O ponto branco representa a posição estimada do usuário, enquanto os retângulos amarelos horizontais mostram as placas de interesse e os vermelhos verticais mostram as portas existentes.

MSER + SURF, bem como os parâmetros escolhidos, podem não apresentar os melhores resultados em relação a técnicas de deteç̧ão de pontos-chave, mas serve como uma base de comparação para validação do método de grafos-chave proposto.

\subsubsection{Precisão e robustez}

A Figura 5.2 mostra alguns resultados de precisão e robustez obtidos pelo aplicativo. Verifica-se que a placa pode ser detectada mesmo com certa mudança no ângulo de visão, bem como sob condições de oclusão parcial. Robustez a variações de escala também são obtidas. Entretanto, como pode ser visto na última linha de imagens, o aplicativo não é capaz de detectar a placa enquanto ela estiver muito distante do usuário. Além disso, se a parte visível da placa não contiver regiões muito significativas (no caso das placas, a região mais significativa é onde existe bastante texto) o aplicativo também não consegue detectá-la. Posteriormente, durante a avaliação do método de localização, serão apresentadas informações mais precisas sobre a restrição de proximidade da placa para detecção, i.e., qual a distância máxima da placa para que a deteç̧ão seja possível.

A robustez também foi testada de forma quantitativa, calculando a porcentagem de quadros do vídeo em que a placa foi detectada. Para tanto, os vídeos que correspondem a um passeio por todo o corredor foram desconsiderados, visto que na maior parte desses vídeos, a placa está longe demais para ser detectada. Os demais vídeos foram capturadas em distâncias bem mais próximas às placas, em que, no caso ideal, elas deveriam ser detectadas em todos os quadros. A Tabela 5.1 mostra os resultados obtidos.

Pela análise dos resultados, verifica-se que o método proposto funciona corretamente na maior 

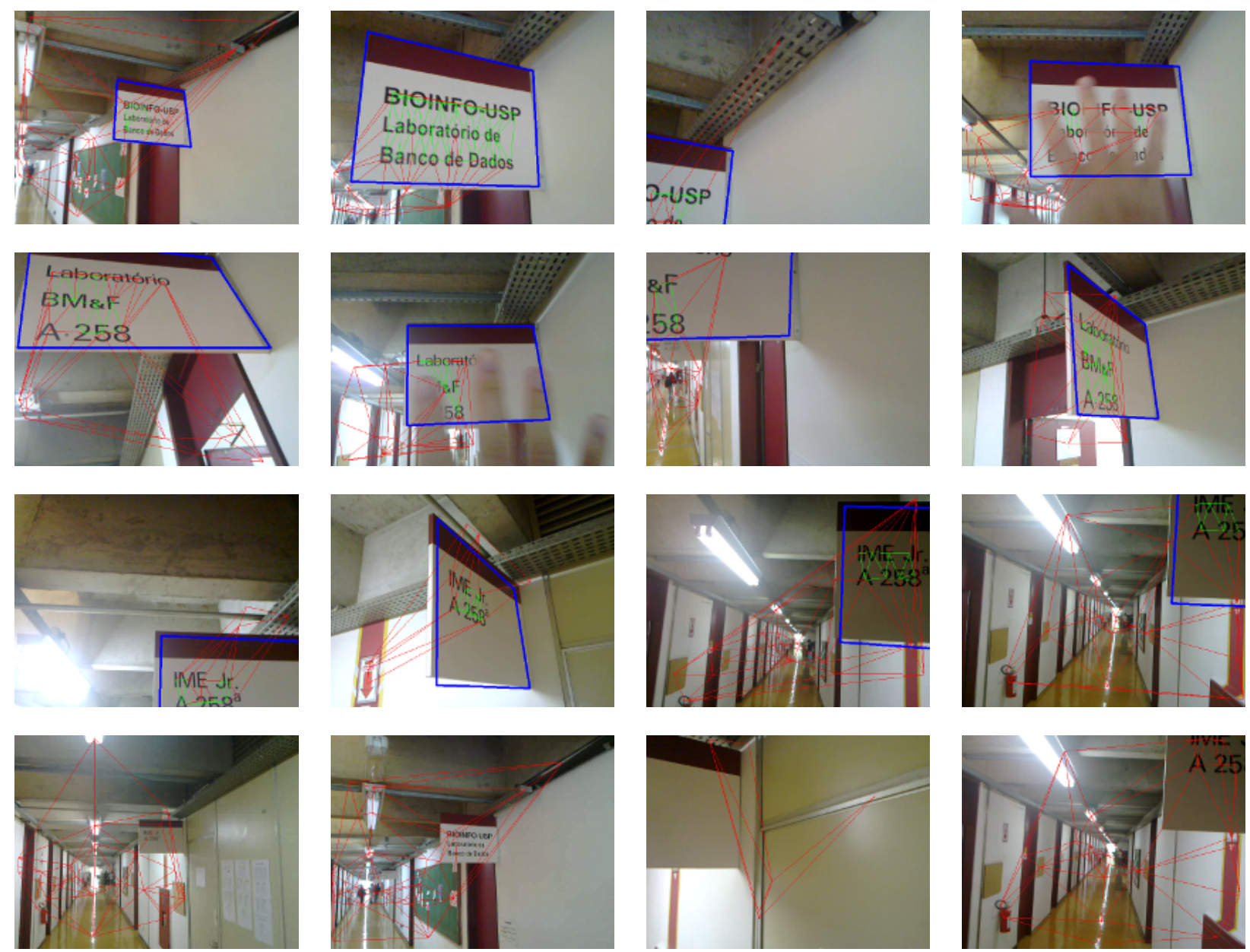

Figura 5.2: Deteç̧ão de placas pelo aplicativo.

Tabela 5.1: Comparação de taxa de detecções positivas de placas.

\begin{tabular}{|c|c|}
\hline Método & Taxa de detecção \\
\hline \hline Grafos-chave & 0,746 \\
Pontos-chave & 0,504 \\
\hline
\end{tabular}

parte do tempo. Ainda que a quantidade de falhas seja significativa, dada a dinamicidade de uma sequência de vídeo, bem como se for assumido que a taxa de transição de quadros é suficientemente alta, tal fato não afetará tão significativamente o resultado para o usuário.

\subsubsection{Análise de tempo}

A fase de deteç̧ão pode ser dividida em quatro partes principais que compõem todo o processo:

- detecção dos pontos-chave: aplicação de algum detector qualquer de pontos-chave, neste caso, o MSER;

- cálculo dos descritores: no caso dos grafos-chave, corresponde também à fase de criação dos arcos dos grafos de onde os descritores são obtidos;

- casamento modelo / cena: casar cada ponto ou grafo da cena com todos os seus correspondentes nas imagens modelo cujos descritores sejam semelhantes. Ao final desta fase, são obtidos os 
candidatos a melhor modelo;

- estimativa de pose e escolha do melhor modelo: calcular a matriz de projeção de cada um dos modelos candidatos na cena e decidir qual deles possui a maior quantidade de correspondências válidas.

A Figura 5.3 mostra o gráfico do tempo médio observado para cada uma das fases. Tais valores foram obtidos calculando-se a média do tempo decorrido em cada quadro dos vídeos usados para se obter os resultados mostrados anteriormente.

\section{3 modelos}

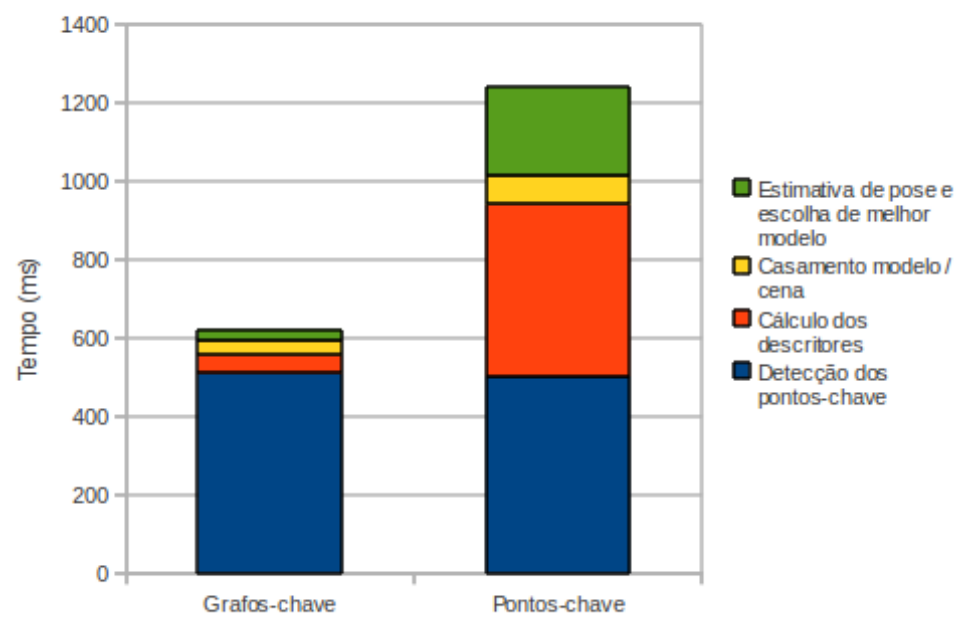

Figura 5.3: Comparação de tempo médio decorrido para cada passo da deteç̧ão usando 3 imagens modelo.

Ao analisar tais resultados, fica claro o ganho que pode ser obtido com o uso dos grafos-chave. Devido à maior simplicidade de seus descritores, são observadas reduções significativas durante a fase de descrição da imagem. Além disso, pela mesma razão, a fase de casamento e escolha de modelo também são fortemente beneficiadas. Considerando então o processo como um todo, verifica-se que tais contribuições permitem que o uso de grafos-chave realizem a detecção em praticamente metade do tempo do uso de pontos-chave, um aumento significativo de desempenho para o tratamento em tempo real.

Entretanto, tais testes consideraram apenas o uso de 3 imagens modelo, que pode ser considerado uma quantidade pequena de objetos para uma aplicação de localização num ambiente maior. Nesse sentido, é importante também verificar o comportamento do método de detecção conforme a quantidade de modelos utilizados cresce. Para tanto, realizou-se também testes adicionais variando a quantidade de modelos para verificar a escalabilidade do método proposto. As quantidades escolhidas foram 3, 15, 50, 500 e 1000 modelos, compostos da seguinte forma:

- 3 modelos: apenas uma imagem de cada uma das 3 placas que se desejava detectar;

- 15 modelos: cada uma das 3 placas foi capturada 5 vezes de forma independente, causando mudanças de escala e de iluminação;

- 50 modelos: além das 15 imagens do conjunto anterior, foram adicionadas 35 imagens de objetos não relacionados ao problema em questão; 
Tabela 5.2: Desempenho do método de grafos-chaves de acordo com o número de modelos usados.

\begin{tabular}{|c|c|c|}
\hline Quantidade de modelos & Casamento (ms) & Pose + escolha de modelo (ms) \\
\hline \hline 3 & 38 & 27 \\
15 & 39 & 31 \\
50 & 53 & 51 \\
500 & 111 & 53 \\
1000 & 177 & 54 \\
\hline
\end{tabular}

- 500 modelos: cada uma das 50 imagens do conjunto anterior foi redimensionada automaticamente em 10 diferentes escalas;

- 1000 modelos: cada uma das 50 imagens do conjunto anterior foi redimensionada automaticamente em 20 diferentes escalas;

A Tabela 5.2 mostra os resultados obtidos com cada um dos conjuntos de modelos citados. Como as fases de deteç̧ão de pontos-chave e construção e descrição de grafos-chave independem da quantidade de modelos, são apresentados apenas os resultados de tempo para as fases de casamento de grafos-chave e estimativa de pose.

É possível observar que, mesmo aumentando em mais de 300 vezes a quantidade de modelos, o tempo decorrido nas duas fases analisadas aumenta em menos de 4 vezes. Tais resultados demonstram que, como esperado, o método é bastante escalável e adequado para dispositivos móveis mesmo se for necessário utilizar diversos pontos de referências simultaneamente. A Figura 5.4 mostra novamente uma comparação do tempo decorrido em cada fase para as abordagens de grafos-chave e pontos-chave, mas utilizando 500 modelos. Optou-se por comparar os métodos usando apenas 500 modelos, ao invés de 1000, pois o método de pontos-chave não foi capaz de executar no dispositivo com a maior quantidade de modelos. Tal fato se deveu à grande quantidade de memória necessária para armazenar o índice com os descritores de pontos-chave, que excedeu as capacidades do dispositivo.

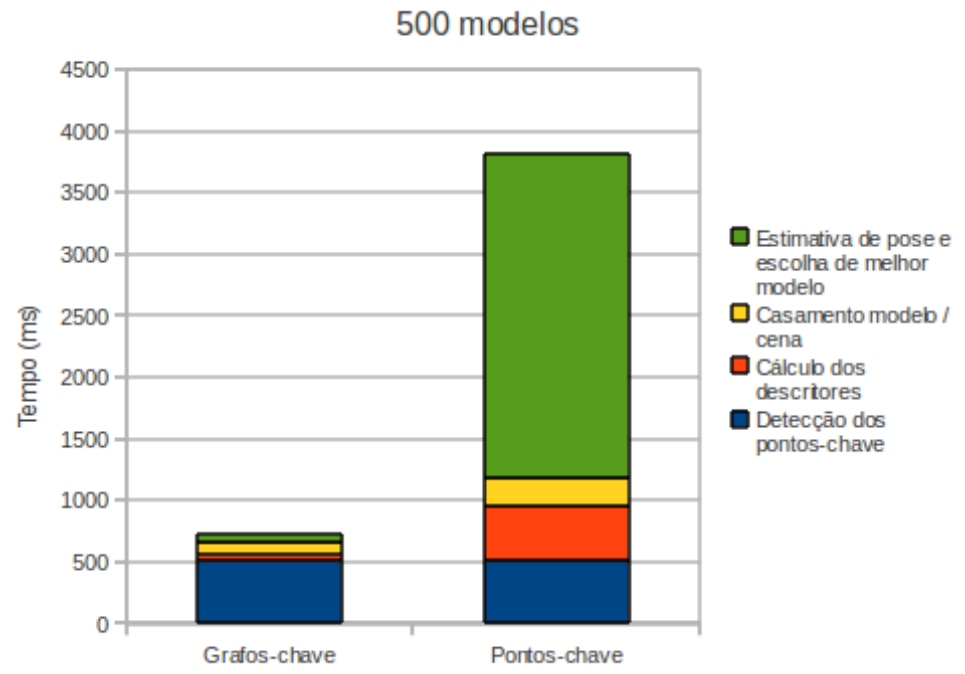

Figura 5.4: Comparação de tempo médio decorrido para cada passo da detecção usando 500 imagens modelo.

Nota-se novamente que o uso dos descritores reduzidos impacta fortemente também na escalabilidade, uma vez que a fase de estimativa de pose cresce significativamente com o uso de pontos-chave 
e passa a dominar o tempo de execução de cada quadro.

\subsection{Estimativa de localização}

A Figura 5.5 mostra alguns resultados de localização mostrados pelo aplicativo. Observando-se as imagens obtidas, é possível verificar que a localização é relativamente confiável, apresentando uma boa estimativa da posição do usuário em relação à placa detectada.
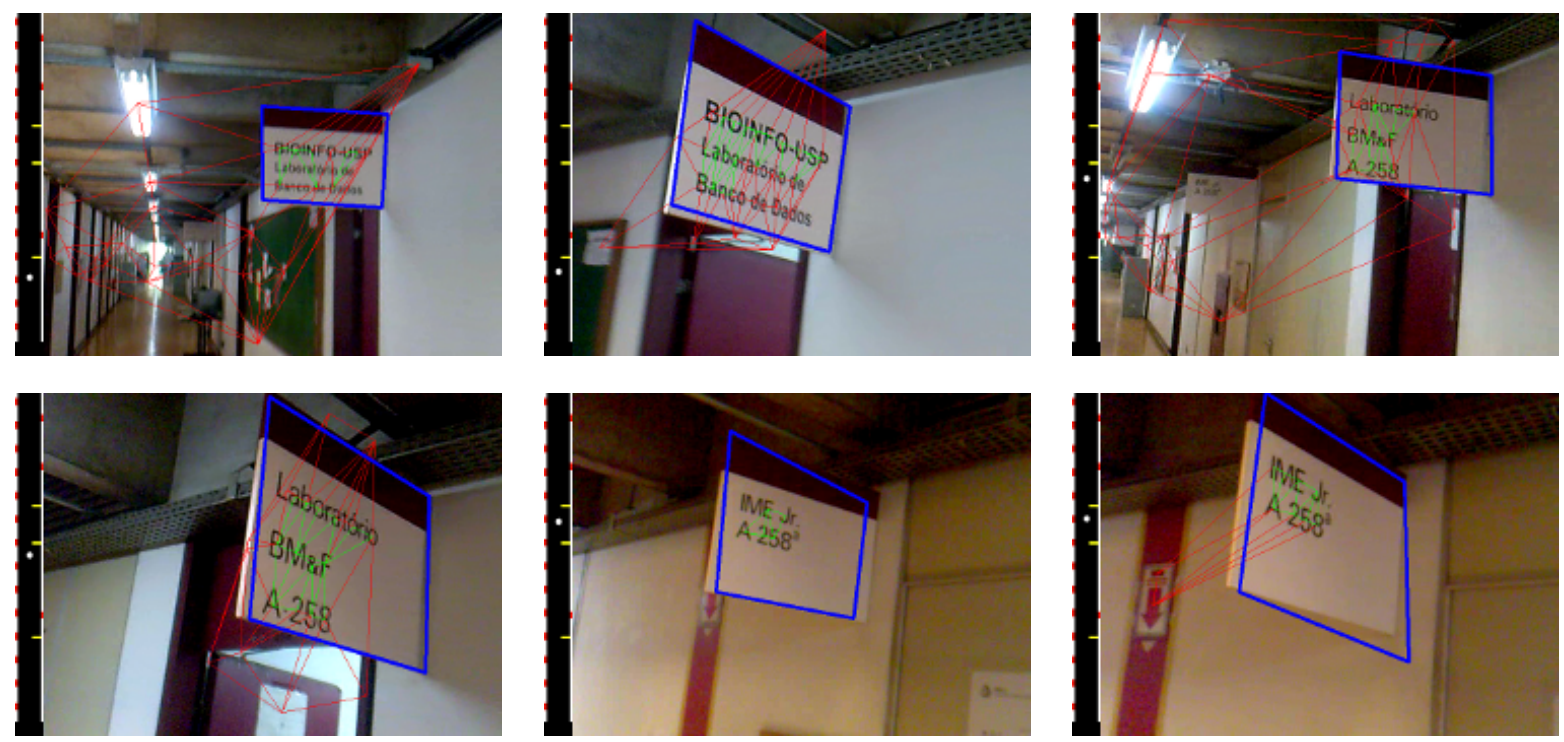

Figura 5.5: Estimativa de localização. O ponto branco no lado esquerdo da imagem mostra a posição estimada no corredor a partir da placa detectada.

Entretanto, apesar de a avaliação subjetiva indicar que o método é confiável, é importante se realizar uma análise mais profunda para se avaliar quantitativamente a real precisão obtida. Neste sentido, na seção a seguir será apresentada a forma de validação utilizada para se avaliar os resultados de localização.

\subsubsection{Validação por morphing}

A fim de realizar uma análise mais profunda sobre a precisão do método de localização, os resultados foram verificados utilizando como entrada as imagens da própria base de dados, descrita na seção 4.1, em que a posição real do usuário no ambiente já é conhecida. Dessa forma tal informação pode ser usada para comparar com a posição estimada pelo aplicativo a fim de verificar quantitativamente a precisão do método implementado.

Entretanto, somente as imagens presentes na base de dados inicial não apresentam amostras suficientes para se realizar uma boa análise de precisão. Isso se dá por duas razões: (i) as imagens de interesse sempre foram capturadas somente do meio do corredor com a câmera apontando diretamente para a frente e (ii) o intervalo de espaço entre duas capturas consecutivas é grande demais para se analisar adequadamente a precisão do aplicativo.

Na Figura 5.6 pode-se ver porque a primeira das razões citadas causa um problema para avaliação das placas nas imagens.

Como não havia um interesse específico em se capturar as placas, mas o corredor como um todo, 

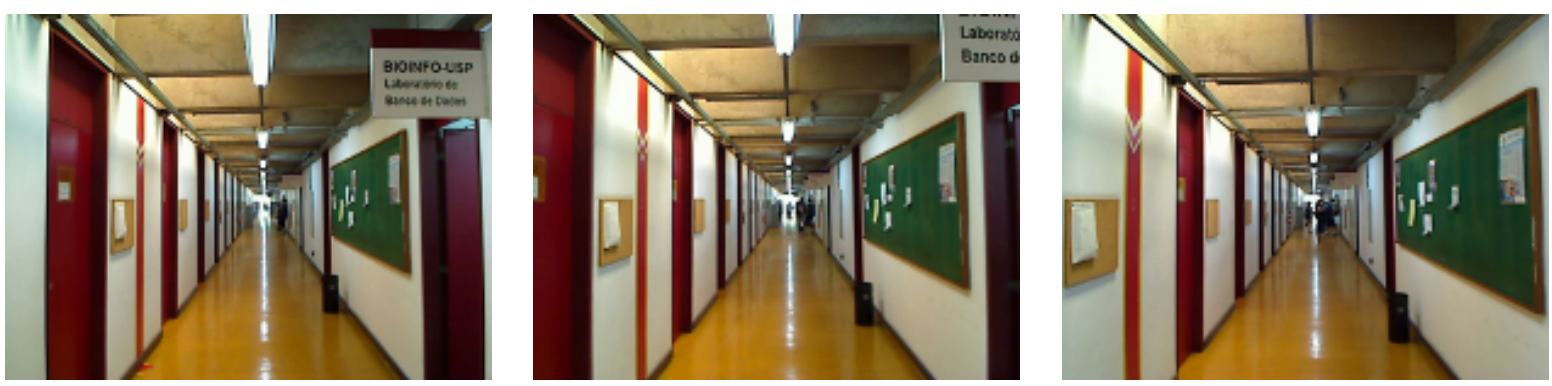

Figura 5.6: Problema com o uso da base de imagens original. A placa nem sempre pode ser vista totalmente, mesmo quando a câmera está antes da placa.

quando a câmera se aproxima demais das placas, estas acabam não sendo capturadas totalmente na imagem. Todas as imagens na Figura 5.6 foram capturadas em pontos antes da placa, mas em alguns casos, como pode ser visto na última imagem, ela nem mesmo está visível. Isso não é interessante para a avaliação da precisão da localização pois pode impossibilitar totalmente sua detecção e, consequentemente, a estimativa de localização.

A fim de se contornar este problema, foram realizadas novas capturas das placas nas posições anteriores à placa, a partir de onde a base de dados original não mostra a área total de cada placa na imagem. Neste caso somente a posição da câmera foi alterada, de forma que toda a placa fosse visível na imagem. Além disso, o intervalo de espaço entre cada captura foi reduzido de $60 \mathrm{~cm}$ para $30 \mathrm{~cm}$. A Figura 5.7 mostra algumas das novas capturas realizadas.
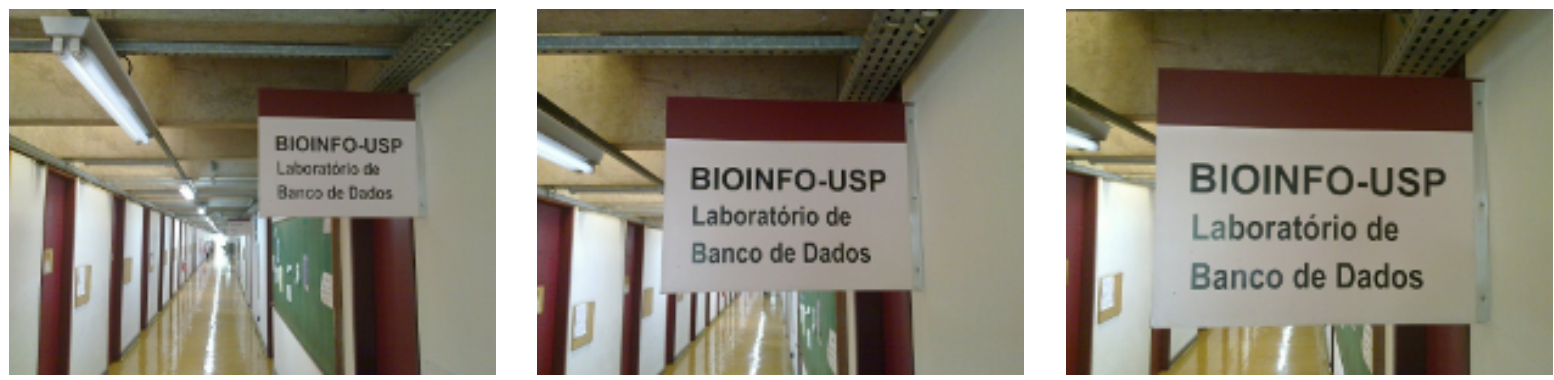

Figura 5.7: Novas imagens capturadas das placas e adicionadas à base de dados.

O segundo problema, o grande intervalo entre duas capturas consecutivas, impossibilita uma avaliação mais fina da localização. A utilização de pontos tão díspares não oferece resultados muito interessantes para avaliação. Seria ideal então, que fossem utilizadas imagens capturadas em alguns pontos intermediários entre duas capturas da base de dados. Uma alternativa óbvia para tanto seria simplesmente capturar mais imagens no ambiente e adicionar à base, tal como foi feito em relação ao primeiro problema. Entretanto, para se obter uma amostra significativa, seriam necessárias diversas capturas a intervalos muito pequenos, que apresentam dificuldades tanto em relação ao grande trabalho envolvido na captura de tantas imagens, bem como à dificuldade de garantir que o intervalo fosse corretamente medido fisicamente.

Neste sentido optou-se por utilizar o morphing, uma técnica de processamento de imagens que utiliza apenas as imagens já existentes para a geração de modelos intermediários. O morphing é uma técnica que combina interpolação e translação para transformar uma imagem em outra. Ao aplicar esta técnica sobre duas imagens, obtém-se uma sequência de imagens intermediárias que 
representa a transição ocorrida entre ambas. Para garantir que o morphing seja efetuado de forma correta e simples, uma abordagem comum é adicionar alguns marcadores de correspondências de pontos em ambas as imagens para guiar o processo.
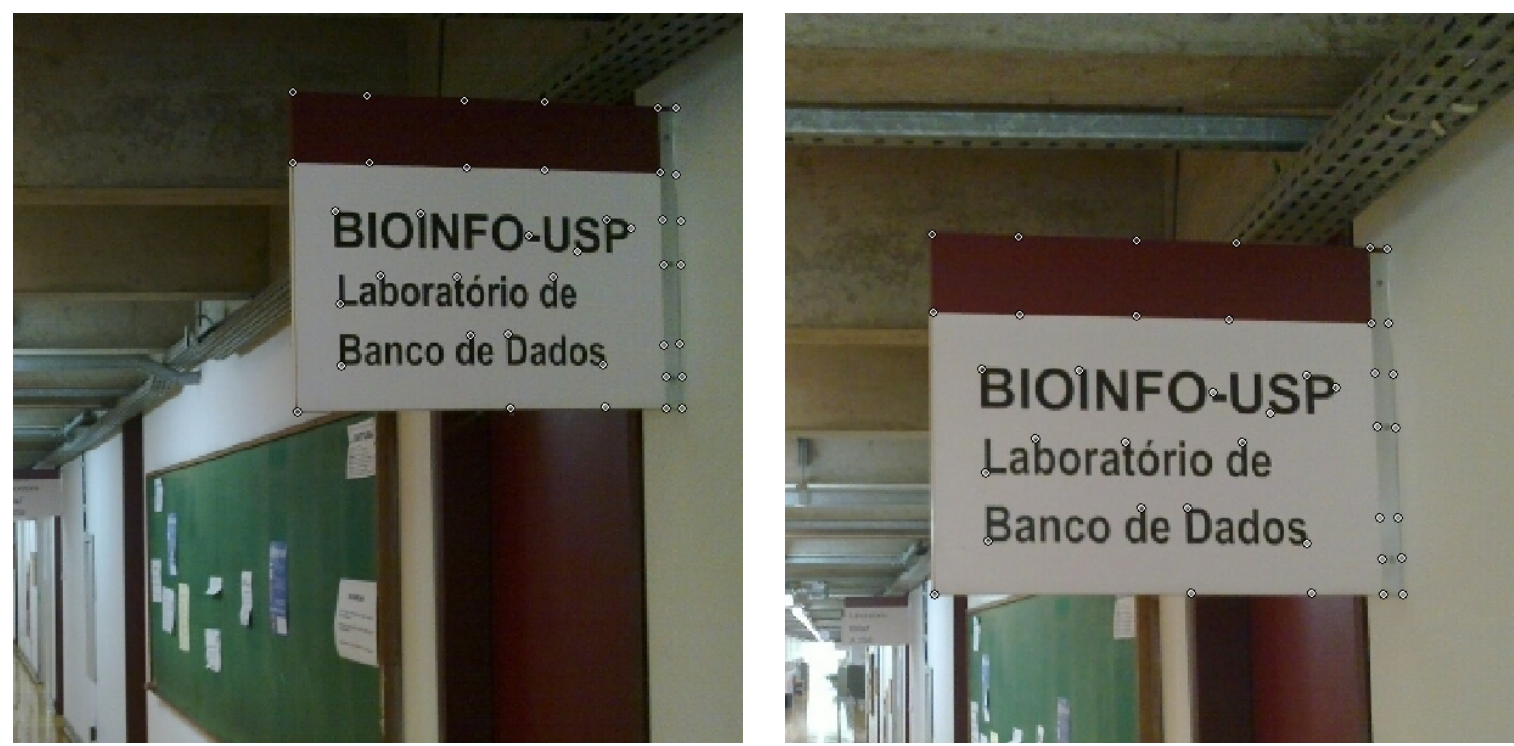

Figura 5.8: Marcações feitas sobre as imagens para o morphing.

O morphing foi realizado utilizando-se o programa Sqirlz Morph ${ }^{2}$. Como o único interesse era de que a placa fosse corretamente transformada no processo, todas as marcações foram feitas somente sobre ela (Figura 5.8). Finalmente, baseando-se nas marcações aplicadas, o morphing gera diversas imagens que demonstram as fases intermediárias de interpolação entre as duas imagens. A Figura 5.9 mostra alguns exemplos de imagens obtidas ${ }^{3}$. Verifica-se que há uma certa distorção no ambiente ao redor durante o processo, mas a placa em si, é transformada consistentemente, tal como esperado.

Para cada par de imagens da base de dados original, foram geradas 19 imagens intermediárias de transição. Dessa forma, como o intervalo original entre cada captura era de $60 \mathrm{~cm}$, assume-se agora que o novo intervalo é de $60 / 20=3 \mathrm{~cm}$ entre cada imagem. O mesmo processo foi realizado sobre as novas imagens capturadas. Neste caso, porém, como o intervalo entre cada captura foi de $30 \mathrm{~cm}$, para cada par de imagens foram geradas 10 imagens intermediárias, de forma a manter o mesmo intervalo de $3 \mathrm{~cm}$ de separação.

Usando então este novo conjunto de imagens como entrada para a avaliação de precisão da estimativa de localização, foram comparadas os valores estimados com as posições reais de cada imagem. A Figura 5.10 mostra os resultados observados.

O gráfico apresenta uma comparação da posição real, representado pela linha contínua, formada ao se representar um ponto a cada $3 \mathrm{~cm}$, com a posição estimada pelo aplicativo para cada imagem dada. O eixo $x$ do gráfico representa a posição real no ambiente, enquanto o eixo $y$ representa a posição estimada. Verifica-se que a estimativa funciona bem para todas as placas, apresentando um erro bem pequeno em qualquer ponto. A Tabela 5.3 mostra algumas estatísticas sobre a estimativa realizada.

Como pode ser visto o erro real médio é praticamente insignificante para a estimativa da posição

\footnotetext{
${ }^{2}$ http://www.xiberpix.net/SqirlzMorph.html

${ }^{3}$ Uma animação de toda a transição pode ser vista em www.vision.ime.usp.br/ henriquem87/mestrado/ dissertacao/morphing/
} 

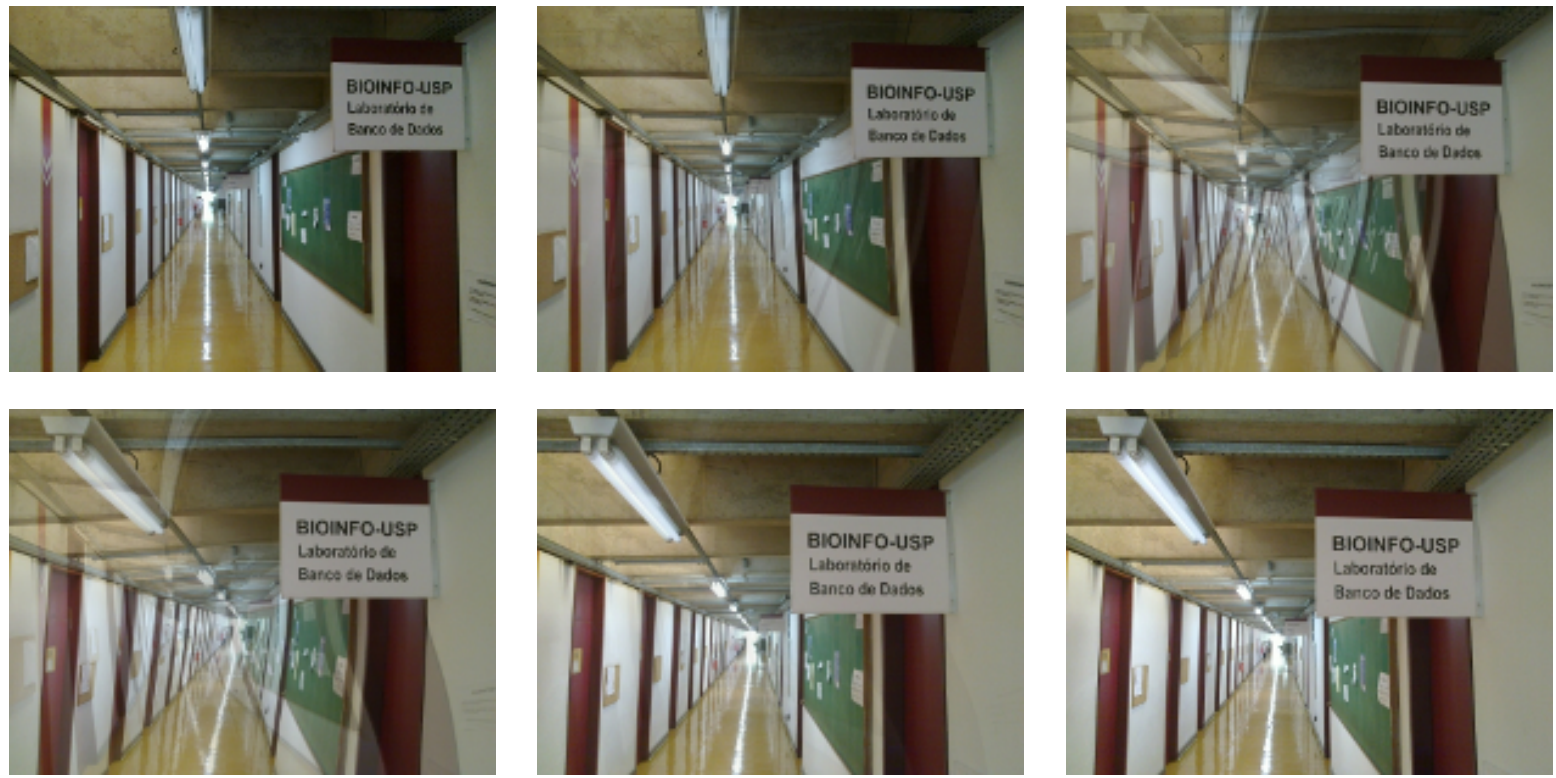

Figura 5.9: Imagens intermediárias obtidas por morphing. A primeira e a última figuras são as imagens originais da base de dados, usadas como referência para o morphing.

Tabela 5.3: Testes de precisão da estimativa de localização.

\begin{tabular}{|l|r|}
\hline Erro médio & $18,6 \mathrm{~cm}$ \\
\hline Desvio padrão & $9,7 \mathrm{~cm}$ \\
\hline Distância máxima média de detecção & $2,5 \mathrm{~m}$ \\
\hline
\end{tabular}

real do usuário no ambiente. Isso demonstra que apesar de simples, o método de localização é muito eficaz. Ressalta-se entretanto, que a estimativa é sempre realizada assumindo que o usuário esteja localizado no meio do corredor, sem estimar o ângulo de visão do mesmo em relação à placa. Além disso como também pode ser visto na Figura 5.10 a localização não pode ser estimada enquanto o usuário está muito distante da placa, como mostrado nas áreas em que não há resultado da estimativa de localização. 


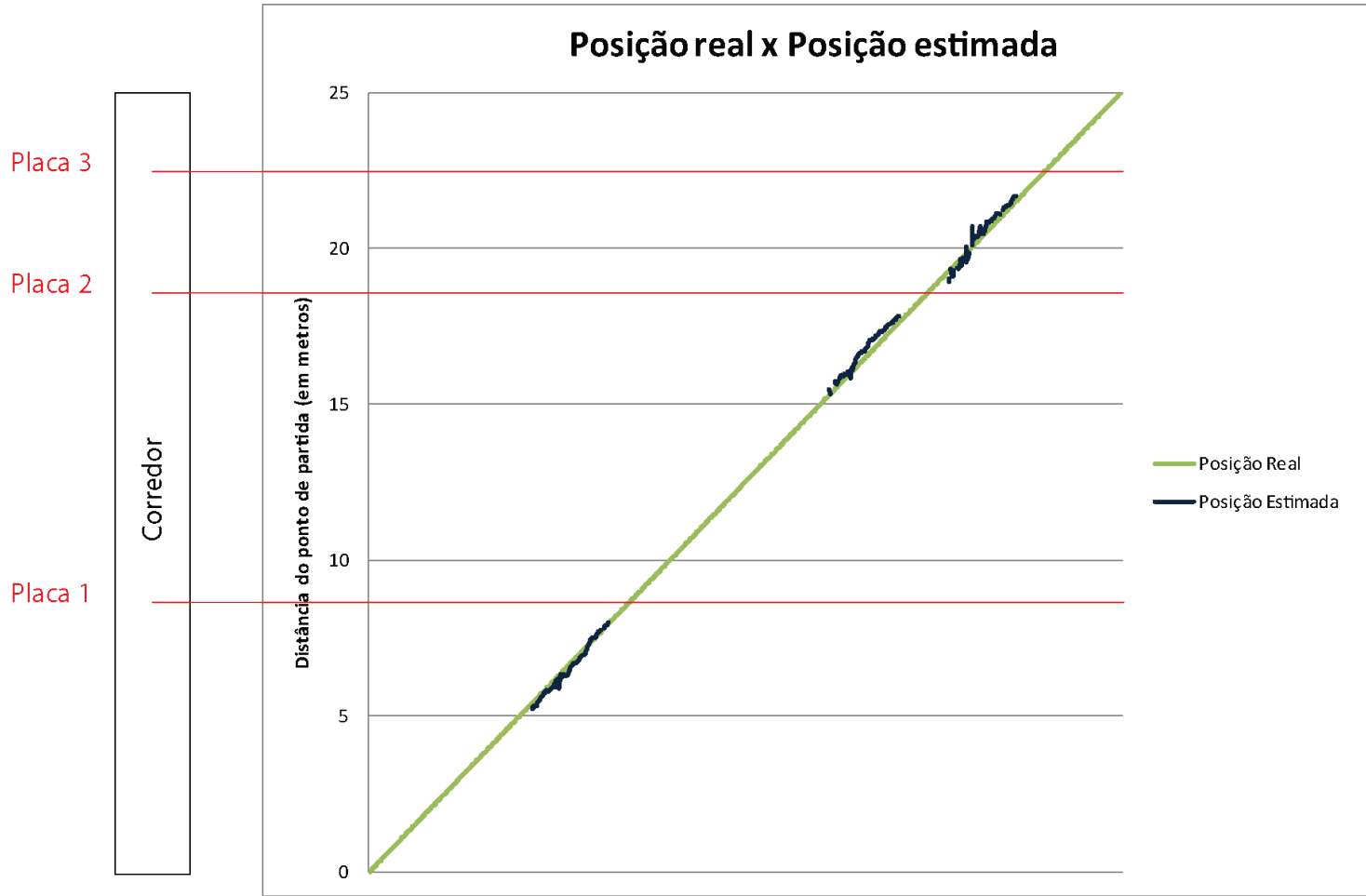

Figura 5.10: Comparativo da posição real no corredor com a posição estimada pelo aplicativo. No lado esquerdo é mostrado um desenho esquemático do corredor e a posição real das placas (linhas em vermelhos). Considera-se que o trajeto foi iniciado na borda inferior (ponto 0) e seguiu de forma retilinea ao longo do corredor. No gráfico à direita, a linha verde (mais clara) mostra a posição real do usuário no corredor. Os pontos azuis (mais escuros) mostram a posição estimada pelo aplicativo quando uma placa é detectada. 


\section{Capítulo 6}

\section{Conclusões}

Este trabalho apresentou um método para detecção de placas e estimativa de localização para dispositivos móveis. Tais dispositivos estão cada vez mais presentes no cotidiano de todos e o uso de métodos de detecção de objetos é uma área importante para esse tipo de aparelho e que conta com as mais diversas aplicações, que variam do simples entretenimento ao auxílio de pessoas necessitadas.

A deteç̧ão de objetos pode ser realizada de diversas formas. Neste trabalho, o sistema desenvolvido foi implementado utilizando-se o método de casamento de grafos-chave. Os grafos-chave foram escolhidos especialmente por serem capazes de capturar informações estruturais dos objetos descritos, por meio das relações definidas pelos seus arcos. Tal propriedade se mostrou muito interessante para se tratar a descrição de placas que, em geral, possuem formato e estrutura muito bem definidos e que são componentes muito importantes na sua identificação.

Como visto na Seção 5.1, os grafos-chave se mostraram especialmente importantes devido a seus descritores reduzidos, que contribuem significativamente para o aumento de desempenho em comparação aos mais complexos pontos-chave com descritores SURF. Adicionalmente, ainda que mais simples, tais descritores se mostraram bastante robustos, inclusive obtendo resultados mais favoráveis que o uso de pontos-chave para o problema tratado.

Além da detecção das placas, o aplicativo desenvolvido também se utiliza da informação obtida para realizar a estimativa de localização do usuário no ambiente. O método de localização implementado é de certa forma bastante restritivo, na medida em que só considera a distância do usuário em relação à placa em linha reta. De fato, métodos muito mais precisos de estimativa de localização podem ser implementados, tais como os mostrados por Paucher e Turk (2010) ou Fischler e Bolles (1981). Entretanto, como pode ser observado pelos resultados do primeiro trabalho, ou avaliados pela necessidade de diversos cálculos de projeção do segundo, tais abordagens são consideravelmente caras para um dispositivo móvel.

Outra restrição é que o método de localização necessita de um conhecimento a priori do ambiente, o que difere de trabalhos baseado em, por exemplo, SLAM (Davison et al. (2007); Karlsson et al. (2005)) bastante comum na área de robótica e que são capazes de reconstruir o ambiente de forma dinâmica. Entretanto, novamente, métodos mais avançados, como o citado, frequentemente têm um alto custo computacional, o que é especialmente importante para dispositivos móveis. Além disso, como o foco do trabalho sempre foi o de realizar uma detecção mais precisa e confiável, seria importante que o método de localização não impactasse na performance do aplicativo. Neste sentido, o método de proposto baseado simplesmente na comparação da informação obtida da deteç̧ão com a base de dados de imagens pré-existentes, cumpre seu objetivo, uma vez que seu resultado pode 
ser obtido praticamente de forma instantânea.

Optou-se por deixar todo o processamento a cargo do próprio dispositivo móvel, sem contar com equipamento externo para auxiliar no processo. A razão para tanto é que, primeiramente, criar esse tipo de dependência afeta uma das características mais interessantes desses aparelhos, que é justamente a sua mobilidade. Além disso, se por um lado tal escolha pudesse agilizar o processamento de grandes volumes de dados, por outro isso também traz uma complexidade adicional para o gerenciamento do processo como um todo. O tempo necessário para tratar da transferência e sincronização dos dados, bem como a própria latência que é inerente a esse tipo de operação, como mostrado em trabalhos anteriores, leva tempo considerável.

O aplicativo implementado foi testado diretamente num celular, um dispositivo móvel de relativa baixa capacidade. O método de deteç̧ão por grafos-chave foi testado sob as mais diversas condições no ambiente escolhido. Pelos resultado obtidos, verificou-se que existia uma certa dificuldade em detectar placas localizadas a grandes distâncias da câmera. Porém, uma vez que ela se aproximava a detecção era possível mesmo sob condições adversas como mudanças de perspectiva, iluminação e oclusão parcial das placas.

Outro resultado importante para este tipo de problema é o tempo de resposta ao usuário. Como o aplicativo estará sendo executado ao mesmo tempo em que o usuário navega pelo ambiente, é importante que o resultado seja dado num intervalo razoável, de forma que a informação obtida seja relevante. Para avaliar o desempenho geral do aplicativo, foi calculado o tempo médio de reposta obtido após a execução de diversos tipos de casos de testes, variando de passeios em todo o corredor à detecção de uma única placa. O resultado de tempo obtido após essa análise, apesar de não ser capaz de oferecer respostas na frequência necessária para ser imperceptível ao usuário, ainda foi bastante razoável. Novamente, como a situação de uso comum do aplicativo desenvolvido consiste em um usuário caminhando em um ambiente, não é necessário que a resposta seja tão rápida e frequente, pois num curto espaço de tempo é muito improvável que haja uma locomoção muito significativa dentro do ambiente.

\subsection{Sugestões para trabalhos futuros}

Em casos em que se fizer necessária uma resposta mais rápida e frequente, é possível, uma vez que a placa fosse corretamente detectada, interromper o processo de detecção e passar a utilização um método mais simples e eficiente de rastreamento, tal como o fluxo óptico Lucas e Kanade (1981). O método de rastreamento também poderia auxiliar durante a deteç̧ão. Trabalhos como o de Mooser et al. (2008) mostram formas de se diminuir o processamento de deteç̧ão de objetos a cada quadro de um vídeo, simplesmente fazendo com que ele seja dividido e processado em partes. O rastreamento é utilizado para manter os pontos já detectados atualizados com a nova cena de forma relativamente robusta, e sem ter um grande custo computacional.

Outra adição interessante, seria permitir que o usuário obtivesse alguma resposta mesmo quando o aplicativo não detectasse nenhuma placa na imagem. Por se utilizar somente da informação obtida imediatamente após uma deteç̧ão para estimar a posição do usuário, quando este deixa de visualizar uma placa, imediatamente a resposta é interrompida. Uma forma de permitir que isso não ocorresse seria utilizar algum método de estimação, como por exemplo, um filtro de Kalman para manter a informação de localização até que outra placa fosse detectada. Outra opção seria usar uma forma 
complementar de localização, que fosse capaz de funcionar em locais mais amplos, tal como a abordagem por wi-fi.

Os dispositivos móveis apresentam diversos componentes únicos que não estão presentes em computadores convencionais. Exemplos incluem: o GPS, acelerômetro, magnetômetro, giroscópio, ou até mesmo um barômetro. Pensando nisso, uma extensão interessante é utilizar as informações obtidas por esses sensores para auxiliar no processamento. Mesmo o uso de GPS, conhecido por não apresentar muito precisos pode ser viável quando combinado com algumas outras formas de localização. Bhatia et al. (2010) mostra uma aplicação interessante de GPS combinado com visão computacional para obter resultados mais precisos e que tornam seu uso viável. Além do GPS, os demais sensores também podem ser usados. Trabalhos como o de Paucher e Turk (2010) mostram formas de se aproveitar de outros sensores de orientação que podem ser úteis em locais fechados. Como normalmente verificar o sinal de um sensor é computacionalmente mais simples do que detectar um objeto, tais alternativas se mostram como opções muito interessantes para dispositivos móveis.

\subsection{Trabalhos publicados}

A pesquisa desenvolvida durante este mestrado possibilitou a publicação de dois artigos. O primeiro no 15th IAPR TC-15 Workshop on Graph-based Representation - GbR'11 (Morimitsu et al. (2011a)), o mais importante workshop de aplicação de grafos para reconhecimento de padrões. O segundo, descrevendo a integração com o sistema de Wi-Fi, foi apresentado no segundo IEEE International Workshop on Mobile Vision (Morimitsu et al. (2011b)), que foi realizado em conjunto com a Internationa Conference on Computer Vision (ICCV), um dos maiores eventos de visão computacional. 
CONCLUSÕES 


\section{Referências Bibliográficas}

Ambai e Yoshida(2011) Mitsuru Ambai e Yuichi Yoshida. Card: Compact and real-time descriptors. Em IEEE International Workshop on Mobile Vision (in conjunction with ICCV 2011). Citado na pág. 6

Arth et al.(2009) Clemens Arth, Daniel Wagner, Manfred Klopschitz, Arnold Irschara e Dieter Schmalstieg. Wide area localization on mobile phones. Em Proceedings of IEEE International Symposium on Mixed and Augmented Reality (ISMAR), páginas 73-82. Citado na pág. 6

Baatz et al.(2010) Georges Baatz, Kevin Köser, David Chen, Radek Grzeszczuk e Marc Pollefeys. Handling urban location recognition as a $2 \mathrm{~d}$ homothetic problem. Em Proceedings of the 11th European conference on Computer vision: Part VI, ECCV'10, páginas 266-279, Berlin, Heidelberg. Springer-Verlag. Citado na pág. 7

Bagherinia e Manduchi(2011) Homayoun Bagherinia e Roberto Manduchi. Robust real-time detection of multi-color markers on a cell phone. Journal of Real-Time Image Processing, 6. Citado na pág. 5,6

Bay et al.(2008) Herbert Bay, Andreas Ess, Tinne Tuytelaars e Luc Van Gool. Surf: Speeded up robust features. Computer Vision and Image Understanding (CVIU), 110(3):346-359. Citado na pág. 1,6

Beis e Lowe(1997) Jeffrey S. Beis e David G. Lowe. Shape indexing using approximate nearestneighbour search in high-dimensional spaces. Em In Proc. IEEE Conf. Comp. Vision Patt. Recog, páginas 1000-1006. Citado na pág. 10

Bhatia et al.(2010) MPS Bhatia, Saurav Kumar, Akshi Kumar e Amit Kothari. Article: Visual aided gps navigation for autonomous mobile robots. International Journal of Computer Applications, 1(25):11-19. Published By Foundation of Computer Science. Citado na pág. 39

Bigham et al.(2010) Jeffrey P. Bigham, Chandrika Jayant, Andrew Miller, Brandyn White e Tom Yeh. Vizwiz::locateit - enabling blind peopleto locate objects in their environment. Em Computer Vision Applications for the Visually Impaired (CVAVI). Citado na pág. 6

Bothe e Al-Hamdani(2010) Hans-Heinrich Bothe e Sermed Al-Hamdani. Flipps for the blind an object detector for medium distances using concerted fingertip stimulation. Em Conference on Computers Helping People with Special Needs, volume 6180 of LNCS, páginas 275-281. Springer. Citado na pág. 6

Bresenham(1965) J. E. Bresenham. Algorithm for computer controle of a digital plotter. Em IBM Systems Journal, volume 4, páginas 25-30. Citado na pág. 12

Chen et al.(2011) David M. Chen, Georges Baatz, Kevin Köser, Sam S. Tsai, Ramakrishna Vedantham, Timo Pylvänäinen, Kimmo Roimela, Xin Chen, Jeff Bach, Marc Pollefeys, Bernd Girod e Radek Grzeszczuk. City-scale landmark identification on mobile devices. Em CVPR. Citado na pág. 7 
Davison et al.(2007) Andrew J. Davison, Ian D. Reid, Nicholas D. Molton e Olivier Stasse. Monoslam: Real-time single camera slam. IEEE Trans. Pattern Analysis and Machine Intelligence, 29:2007. Citado na pág. 37

de Berg et al.(2008) Mark de Berg, Otfried Cheong, Marc van Kreveld e Mark Overmars. Computational Geometry: Algorithms and Applications. Springer-Verlag, terceira edição. Citado na pág. 14

Fischler e Bolles(1981) M. A. Fischler e R. C. Bolles. Random sample consensus: A paradigm for model fitting with applications to image analysis and automated cartography. Em Communications of the ACM, volume 24, páginas 381-395. Citado na pág. 17, 37

Fortune(1986) S. Fortune. A sweepline algorithm for voronoi diagrams. Em Proceedings of the Second Annual Symposium on Computational Geometry, páginas 313-322. Citado na pág. 15

Gammeter et al.(2010) Stephen Gammeter, Alexander Gassmann, Lukas Bossard, Till Quack e Luc Van Gool. Server-side object recognition and client-side object tracking for mobile augmented reality. Em IEEE International Workshop on Mobile Vision. Citado na pág. 5, 7

Gonzalez e Woods(2008) Rafael C. Gonzalez e Richard E. Woods. Digital Image Processing. Prentice Hall, terceira edição. Citado na pág. 12

Hartley e Zisserman(2004) Richard Hartley e Andrew Zisserman. Multiple View Geometry in Computer Vision. Cambridge University Press, segunda edição. Citado na pág. 16

Hashimoto e Cesar-Jr.(2009) Marcelo Hashimoto e Roberto M. Cesar-Jr. Object detection by keygraph classification. Em Graph-Based Representations in Pattern Recognition, volume 5534, páginas 223-232. Citado na pág. 2

Ivanchenko et al.(2010) Volodymyr Ivanchenko, James Coughlan e Huiying Shen. Real-time walk light detection with a mobile phone. Em Conference on Computers Helping People with Special Needs, volume 6180 of $L N C S$, páginas 229-234. Springer. Citado na pág. 6

Kahäri e Murphy(2006) Markus Kahäri e David J. Murphy. Mara - sensor based augmented reality system for mobile imaging. Em ISMAR. Citado na pág. 7

Karlsson et al.(2005) Niklas Karlsson, Enrico Di Bernardo, Jim Ostrowski, Luis Goncalves, Paolo Pirjanian e Mario E. Munich. The vslam algorithm for robust localization and mapping. Em Proc. of Int. Conf. on Robotics and Automation (ICRA, páginas 24-29. Citado na pág. 37

Kumar et al.(2008) A. Kumar, J.-P. Tardif, R. Anati e K. Daniilidis. Experiments on visual loop closing using vocabulary trees. Em Computer Vision and Pattern Recognition Workshops, 2008. CVPRW '08. IEEE Computer Society Conference on, páginas 1 -8. doi: 10.1109/CVPRW.2008. 4563140. Citado na pág. 7

Leutenegger et al.(2011) Stefan Leutenegger, Margarita Chli e Roland Siegwart. Brisk: Binary robust invariant scalable keypoints. Em IEEE International Workshop on Mobile Vision (in conjunction with ICCV 2011). Citado na pág. 6

Liu et al.(2007) Hui Liu, Houshang Darabi, Pat Banerjee e Jing Liu. Survey of Wireless Indoor Positioning Techniques and Systems. IEEE Transactions on Systems, Man and Cybernetics, Part C (Applications and Reviews), 37(6):1067-1080. Citado na pág. 7

Lowe(2004) David G. Lowe. Distinctive image features from scale-invariant keypoints. International Journal of Computer Vision, 60:91-110. Citado na pág. 1, 6

Lucas e Kanade(1981) Bruce D. Lucas e Takeo Kanade. An iterative image registration technique with an application to stereo vision. Proceedings of the 1981 DARPA Imaging Understanding Workshop, páginas 121-130. Citado na pág. 38 
Matas et al.(2002) J Matas, O Chum, M Urba e T Padja. Robust wide baseline stereo from maximally stable extremal regions. Em Proceedings of British Machine Vision Conference, páginas 384-396. Citado na pág. 9

Mooser et al.(2008) Jonathan Mooser, Quan Wang, Suya You e Ulrich Neumann. Fast simultaneous tracking and recognition using incremental keypoint matching. Citado na pág. 38

Morettin e de Oliveira Bussab(2010) Pedro Alberto Morettin e Wilton de Oliveira Bussab. Estatística Básica. Saraiva, sexta edição. Citado na pág. 18

Morimitsu et al.(2011a) Henrique Morimitsu, Marcelo Hashimoto, Rodrigo B. Pimentel, Roberto M. Cesar-Jr. e Roberto Hirata-Jr. Keygraphs for sign detection in indoor environments by mobile phones. Em Xiaoyi Jiang, Miquel Ferrer e Andrea Torsello, editors, Graph-Based Representations in Pattern Recognition, volume 6658 of Lecture Notes in Computer Science, páginas 315-324. Springer Berlin / Heidelberg. Citado na pág. 39

Morimitsu et al.(2011b) Henrique Morimitsu, Rodrigo B. Pimentel, Marcelo Hashimoto, Roberto M. Cesar-Jr. e Roberto Hirata-Jr. Wi-fi and keygraphs for localization with cell phone. Em IEEE International Conference on Computer Vision Workshops, páginas 92-99. Citado na pág. 39

Muja e Lowe(2009) Marius Muja e David G. Lowe. Fast approximate nearest neighbors with automatic algorithm configuration. Em International Conference on Computer Vision Theory and Application (VISSAPP), páginas 331-340. INSTICC Press. Citado na pág. 10

Mulloni et al.(2009) Alessandro Mulloni, Daniel Wagner, Istvan Barakonyi e Dieter Schmalstieg. Indoor positioning and navigation with camera phones. IEEE Pervasive Computing, 8:22-31. Citado na pág. 5

Paucher e Turk(2010) Rémi Paucher e Matthew Turk. Location-based augmented reality on mobile phones. Em IEEE International Workshop on Mobile Vision. Citado na pág. 5, 7, 37, 39

Ravi et al.(2006) Nishkam Ravi, Pravin Shankar, Andrew Frankel, Ahmed Elgammal e Liviu Iftode. Indoor localization using camera phones. Em Proceedings of the Seventh IEEE Workshop on Mobile Computing Systems and Applications, páginas 1-7. Citado na pág. 7

Shi e Tomasi(1994) Jianbo Shi e Carlo Tomasi. Good features to track. Em IEEE Conference on Computer Vision and Pattern Recognition (CVPR). Citado na pág. 1, 9

Takacs et al.(2008) Gabriel Takacs, Vijay Chandrasekhar, Natasha Gelfand, Yingen Xiong, WeiChao Chen, Thanos Bismpigiannis, Radek Grzeszczuk, Kari Pulli e Bernd Girod. Outdoors augmented reality on mobile phones using loxel-based visual feature organization. Em Proceedings of the 1st ACM Internation Conference on Multimedia Information Retrieval (MIR), páginas 427-434. Citado na pág. 5

Tell e Carlsson(2000) Dennis Tell e Stefan Carlsson. Wide baseline point matching using affine invariants computed from intensity profiles. Em Proceedings of the 6th European Conference on Computer Vision-Part I, volume 1842 of LNCS, páginas 814-828. Springer. Citado na pág. 11, 12

Tell e Carlsson(2002) Dennis Tell e Stefan Carlsson. Combining appearance and topology for wide baseline matching. Em Proceedings of the 7th European Conference on Computer VisionPart I, volume 2350 of $L N C S$, páginas 68-81. Springer. Citado na pág. 11, 12

Tian et al.(2010) YingLi Tian, Chucai Yi e Aries Arditi. Improving computer vision-based indoor wayfinding for blind persons with context information. Em Conference on Computers Helping People with Special Needs, volume 6180 of LNCS, páginas 255-262. Springer. Citado na pág. 6 
Tsui et al.(2009) Arvin Wen Tsui, Yu-Hsiang Chuang e Hao-Hua Chu. Unsupervised learning for solving rss hardware variance problem in wifi localization. Mob. Netw. Appl., 14:677-691. ISSN 1383-469X. Citado na pág. 7

Tuytelaars e Mikolajczyk(2008) Tinne Tuytelaars e Krystian Mikolajczyk. Local invariant feature detectors: a survey. Found. Trends. Comput. Graph. Vis., 3:177-280. ISSN 1572-2740. Citado na pág. 9

Winlock et al.(2010) Tess Winlock, Eric Christiansen e Serge Belongie. Toward real-time grocery detection for the visually impaired. Em Computer Vision Applications for the Visually Impaired (CVAVI). Citado na pág. 6

Yang e Tian(2010) Xiaodong Yang e Yingli Tian. Robust door detection in unfamiliar environments by combining edge and corner features. Em Computer Vision Applications for the Visually Impaired (CVAVI). Citado na pág. 7

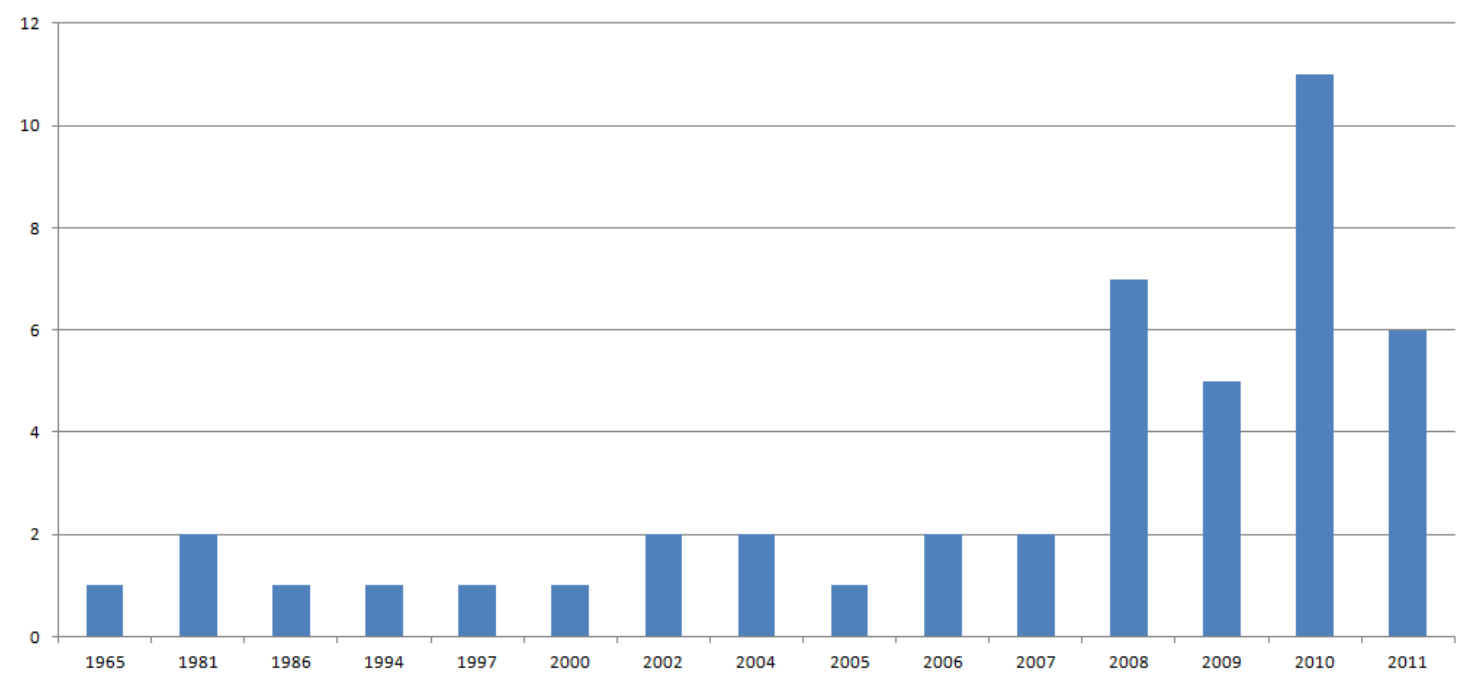

Figura 1: Histograma de referências bibliográficas 